\title{
El diálogo jurisdiccional interregional en la investigación y sanción de la violencia sexual $^{1}$
}

\section{Interregional Jurisdictional Dialogue in the Investigation and Punishmnent of Sexual Violence}

\author{
Magdalena M. Martín ${ }^{2}$ \\ Universidad de Málaga (España)
}

Isabel Lirola ${ }^{3}$

Universidad de Santiago de Compostela (España)

Recibido: $30-08-18$

Aprobado: 16-09-18

\section{Resumen}

En el presente artículo las autoras analizan, desde la óptica del Derecho Internacional Público, la jurisprudencia creciente de la Corte Interamericana de Derechos Humanos y el Tribunal Europeo de Derechos Humanos sobre vulneraciones de derechos humanos en las que se constata la comisión de actos de violencia sexual, incluyendo posibles crímenes internacionales, desde tres perspectivas complementarias: empírica, contextual y sustantiva. El propósito último de este estudio estriba en dirimir si ambos tribunales han entablado un diálogo interregional en esta materia, así como el alcance, pautas, principales notas distintivas y eventuales límites de esta novedosa interacción en la investigación y sanción de una forma de violencia tradicionalmente ausente de sus labores jurisdiccionales.

\footnotetext{
${ }^{1}$ El presente estudio se enmarca en el Proyecto I+D Excelencia 2015, referencia DER201565906-P y en el Proyecto I+D+i Europa Investigación EUIN2017-85437. Magdalena M. Martín se ha encargado de los epígrafes II y V $(1,2,3)$ y a Isabel Lirola corresponde la redacción del III, IV y V (4). Ambas autoras han redactado conjuntamente la introducción y las conclusiones.

2 (magdalena@uma.es) Catedrática de Derecho Internacional Público y Relaciones Internacionales en la Universidad de Málaga.

${ }^{3}$ (isabel.lirola.usc.es) Profesora Titular acreditada a Catedrática de Derecho Internacional Público y Relaciones Internacionales en la Universidad de Santiago de Compostela.
} 
Palabras-clave: diálogo interregional, violencia sexual, deberes de los estados, tipología de crímenes sexuales, similitudes y diferencias en la investigación y sanción

\section{Abstract}

In this article, the authors analyze from the perspective of International Public Law, the growing jurisprudence of the Inter-American Court of Human Rights and the European Court of Human Rights on human rights violations in which the commission of acts of sexual violence is verified, including possible international crimes, from three complementary perspectives: empirical, contextual and substantive. The ultimate purpose of this study is to determine if both courts have engaged in an interregional dialogue on this matter, as well as the scope, guidelines, main distinguishing marks and possible limits of this novel interaction in the investigation and sanction of a form of violence traditionally absent in their jurisdictional work.

Key-words: interregional dialogue, sexual violence, duties of the states, typology of sexual crimes, similarities and differences in the investigation and sanction.

\section{Introducción}

La violencia sexual es hoy un elemento central en la vulneración de varios de los derechos humanos protegidos por el Convenio para la Protección de los Derechos Humanos y de las Libertades Fundamentales (CEDHLF, Convenio de Roma de 4 de noviembre de 1950) y de la Convención Americana de Derechos Humanos (Pacto de San José, de 22 de noviembre de 1969), a pesar de la falta de referencia expresa en el texto de dichos instrumentos. Si bien durante un prolongado periodo de tiempo esta cuestión ha estado ausente de la actividad de la Corte Interamericana de Derechos Humanos (CIDH) y del Tribunal Europeo de Derechos Humanos (TEDH), en los últimos años ambos Tribunales se han ocupado cada vez con más frecuencia de proteger los derechos y las garantías de las víctimas de este particular tipo de violencia frente a las acciones $\mathrm{u}$ omisiones de los Estados parte en sus respectivas cartas constitutivas.

Sin embargo, llama la atención que la labor jurisprudencial de estos dos Tribunales regionales en el ámbito específico de la violencia sexual haya sido objeto tan sólo de relativa atención. Más allá del comentario de sentencias determinadas, se echa en falta un examen de conjunto que, en cualquier modo, ha sido más abundante en el caso de la CIDH, y casi inexistente en lo que respecta 
al $\mathrm{TEDH}^{4}$. Con todo, la atención que se le ha prestado es comparativamente mucho menor que la recibida por la jurisprudencia de los Tribunales Penales Internacionales para la exYugoslavia y Ruanda, o incluso la que han merecido las contadas sentencias hasta ahora dictadas por la Corte Penal Internacional. Igual de sorprendente resulta la ausencia de análisis de esta jurisprudencia temática desde la perspectiva del diálogo inter-jurisdiccional, especialmente si se tiene en cuenta el creciente interés que éste viene despertando en la doctrina en el marco más amplio de un fenómeno contemporáneo clave en el Derecho Internacional Público como es la judicialización ${ }^{5}$, sobre el que luego volveremos.

Estas lagunas pueden encontrar explicación, aunque no justificación, en distintos motivos. Desde una perspectiva general, es necesario recordar una vez más las dificultades que el análisis de la violencia sexual suscita debido a los estereotipos de género que aún siguen presentes en la mayor parte de las sociedades, incluidas las europeas y latinoamericanas ${ }^{6}$, así como los obstáculos que la investigación y sanción de los delitos de esta naturaleza plantean ${ }^{7}$. A ello se le suma que en el plano jurídico-internacional el esfuerzo se haya centrado principalmente en la prevención, protección y sanción de la violencia sexual frente a su uso sistemático y generalizado en las llamadas nuevas guerras. Así, la fundamental contribución llevada a cabo por la jurisprudencia de los Tribunales ad hoc, junto a la inclusión de los crímenes internacionales de violencia sexual en el Estatuto de Roma, podrían haber generado un efecto colateral no deseado consistente en desplazar a un segundo plano la violencia sexual que se perpetra fuera de los conflictos armados. La conclusión perversa de este silogismo sería

\footnotetext{
${ }^{4}$ Por lo que respecta a la CIDH, entre otros, Diana Marcela Bustamante Arango, "La violencia sexual como tortura. Estudio jurisprudencial en la Corte Interamericana de Derechos Humanos" en Revista de la Facultad de Derecho y Ciencias Políticas, 121 (2014), pp. 461-502; Emanuela Cardoso Onofre De Alencar, "Mujeres y estereotipos de género en la jurisprudencia de la Corte Interamericana de Derechos Humanos" en Eunomía. Revista en Cultura de la Legalidad, 9 (2016), pp. 26-48; Laura Clérico; Celeste Novelli, "La violencia contra las mujeres en las producciones de la comisión y la Corte Interamericana de Derechos Humanos" en Estudios Constitucionales, 1 (2014), pp. 15-70; Lorena P. A. Sosa, "Inter-American case law on femicide: Obscuring intersections?" en Netherlands Quarterly of Human Rights, 2 (2017), pp. 85-103.

${ }^{5}$ Entre otros, Andreas Follesdal/Geir Ulfstein, The judicialization of international law: a mixed blessing?, Oxford, Oxford University Press, 2018; American Society of International Law, Charting new frontiers in international law, Proceedings of the 110th annual meeting, March 30-April 2, 2016, Washington, DC; Virginia Petrova Georgieva, "La "judicialización": una nueva característica del sistema jurídico internacional" en Anuario Mexicano de Derecho Internacional, 2015, pp.3-45.

${ }^{6}$ En relación con la situación en América Latina, ver por ejemplo los indicadores sobre autonomía física del Observatorio de Igualdad de género de América Latina y el Caribe, disponible en la dirección https://oig.cepal.org/es. Por lo que respecta a Europa, resulta muy ilustrativa la Estrategia de Igualdad de género, 2018-2023 del Consejo de Europa, cuyo Objetivo estratégico 1 se dedica a la prevención y lucha contra los estereotipos de género y el sexismo, disponible en la dirección rm.coe.int/estrategiade-igualdad-de-genero-del-coe-es-msg/16808ac960Una.

Comisión Interamericana de Derechos Humanos, Acceso a la justicia para las mujeres víctimas de violencia en las Américas, Washington, OEA, 2007, p.ix y Council of Europe, Equal Access to Justice in EHRC Case-law on Violence against Women, 2015, p.5.
} 
atribuir a estos actos de violencia sexual una menor gravedad, por tratarse "únicamente" de una vulneración de los derechos humanos, de ahí que la jurisprudencia del TEDH y la CIDH en la materia también sea considerada de escasa relevancia.

Obviamente, tales razonamientos resultan totalmente falaces, pues los delitos a los que pueden dar lugar los actos de violencia sexual son los mismos, independientemente del contexto en que se cometan, ya que en todos ellos se atenta contra la dignidad, la integridad y la libertad individual. Por tanto, el sufrimiento de las víctimas no varía, con independencia de que concurran o no los elementos necesarios para considerarlos como crímenes internacionales. Además, en este mismo orden de cosas procede resaltar que el tratamiento de la violencia sexual en el Derecho Internacional Público está basado en un proceso de interacción normativa y jurisprudencial en el que, junto con instrumentos y órganos propios del Derecho Internacional Humanitario y el Derecho Internacional Penal, se incluyen las normas del Derecho Internacional de los Derechos Humanos y la jurisprudencia de los órganos jurisdiccionales encargados de su aplicación ${ }^{8}$. Más aun, como tendremos ocasión de comprobar, algunos de los casos que han llegado ante la CIDH y el TEDH por la comisión de actos de violencia sexual en situaciones de conflicto y crisis generalizadas han sido categorizados como crímenes internacionales, en tanto que actos de genocidio, crímenes de lesa humanidad o crímenes de guerra.

Descendiendo desde el plano general a lo particular, al argumentario anterior se añaden otras dos razones por las que el examen de la jurisprudencia del TEDH y la CIDH relacionada con la violencia sexual desde la perspectiva del diálogo jurisdiccional resulta una tarea imprescindible e ineludible. La primera tiene que ver con el papel en la lucha contra la impunidad que desempeñan ambos Tribunales en sus respectivos ámbitos de jurisdicción. A este respecto, partiendo de alguna primera sentencia datada en las últimas décadas del siglo pasado, se han ido multiplicando los asuntos ante los dos tribunales cuyo común denominador es la impunidad de la que se han beneficiado los autores de la violencia sexual, ya sean agentes estatales o particulares. Es por ello que en ambos casos la jurisprudencia ha reforzado el alcance de los deberes estatales de investigación y sanción de la violencia sexual, puesto que, como la CIDH ha señalado, la impunidad "propicia la repetición crónica de las violaciones de derechos humanos y la total indefensión de las víctimas".

La segunda razón se debe precisamente al interés que suscita conocer si efectivamente se ha entablado un verdadero diálogo en la protección de los derechos que se ven vulnerados como consecuencia de los actos de violencia

\footnotetext{
8 Isabel Lirola Delgado/Magdalena Martín Martínez, Crímenes Internacionales de violencia sexual y conflictos armados, Cizur Menor, Thomson Reuters, 2016, pp.37-61.

${ }^{9} \mathrm{CIDH}$, Caso del Penal Miguel Castro Castro contra Perú, Sentencia de 25 de noviembre de 2006 (Fondo, Reparaciones y Costas), párr.405.
} 
sexual, en el marco más amplio de las dinámicas y tendencias a las que responde dicho diálogo como un fenómeno, que aunque horizontal y voluntario, también resulta predominantemente unidireccional ${ }^{10}$. En principio, el diálogo interregional en materia de violencia sexual obedecería a estas mismas pautas, puesto que si se atiende meramente al criterio de las citas recíprocas, el TEDH parecería estar ignorando la jurisprudencia de la $\mathrm{CIDH}$, frente a la receptividad de ésta ${ }^{11}$.

No obstante, la unidireccionalidad podría ser más aparente que real, de modo que en la actualidad las respectivas construcciones jurisprudenciales frente a la violencia sexual estaría deviniendo en uno de los ámbitos más fructíferos del diálogo interregional. A este respecto, como se ha señalado aunque "el TEDH no recurre con frecuencia a citas explícitas de la jurisprudencia interamericana, las influencias implícitas son notables, ya que en muchos ámbitos es apreciable una verdadera y propia convergencia interpretativa entre las jurisprudencias de las dos Cortes" 12 . Por tanto, la premisa de partida del presente trabajo es la existencia de un diálogo interregional, tanto expreso como subliminal, en relación a la vulneración de los derechos humanos protegidos por el Convenio de Roma y la Convención de San José por la comisión de actos de violencia sexual, incluidos los que por su gravedad constituyan crímenes internacionales. $\mathrm{Su}$ objetivo último, analizar el alcance, las principales notas distintivas y los eventuales límites de este novedoso diálogo interregional

Con tal fin, a modo de prólogo necesario explicaremos el papel de ambos tribunales en el tratamiento de la violencia sexual en el sistema de justicia penal internacional (II), para a renglón seguido examinar la jurisprudencia de la CIDH y el TEDH sobre esta materia desde tres perspectivas complementarias: empírica, contextual y sustantiva. En virtud de la primera aproximación, abordaremos la jurisprudencia conforme a unos parámetros cuantitativos y cualitativos para contrastar su encaje en los patrones genéricos que habitualmente se predican del diálogo birregional (III). En segundo lugar, llevaremos a cabo una aproximación contextual a partir de la identificación de los elementos fácticos, particulares y

${ }^{10}$ Por todos, Francisco Javier Ansuátegui Roig, "Human Rights and Judicial Dialogue between America and Europe: Toward A New Model Of Law?" en The Age of Human Rights Journal", 6 (2016) p. 8; Joaquín García Roca, Humberto Nogueira Alcalá, Rafael Bustos Gisbert, "La comunicación entre ambos sistemas y las características del diálogo", (en Joaquín García Roca, Pablo Antonio Fernández, Pablo Santolaya, Raúl Canosa, eds: El diálogo entre los Sistemas Europeo y Americano de Derechos Humanos, Cizur Menor, Thomson Reuters, 2012, p.76.

11 Resulta indicativo que una única sentencia de la CIDH, Sentencia de 20 de noviembre de 2014 (Excepciones Preliminares, Fondo, Reparaciones y Costas), figure como muestra del diálogo interregional en esta materia en la publicación auspiciada por el Consejo de Europa y la Corte Interamericana Dialogue Across the Atlantic: Selected Case-Law of the European and Inter-American Human Rights Courts, Oisterwijk, Wolf Legal Publishers (WLP), 2015, pp. 519-571.

12 Tania Groppi, Anna Maria Lecis Cocco-Ortu, "Las referencias recíprocas entre el Tribunal Europea y la Corte Interamericana de Derechos Humanos: ¿de la influencia al diálogo?” en Revista de Derecho Político-UNED, 91(2014), p.225.

Araucaria. Revista Iberoamericana de Filosofia, Politica, Humanidades y Relaciones Internacionales, año 20, $\mathrm{n}^{\circ} 40$. Segundo semestre de 2018. Pp. 511-575. ISSN 1575-6823 e-ISSN 2340-2199 doi: 10.12795/araucaria.2018.i40.23 
comunes, en los casos de violencia sexual ante la CIDH y el TEDH, a pesar de las distintas realidades sociales y políticas existentes en América Latina y Europa (IV). En tercer lugar, realizaremos un análisis sustantivo de la jurisprudencia de ambos Tribunales para analizar los principales aspectos en los que el diálogo se ha manifestado (V). Finalmente, formularemos unas conclusiones tentativas sobre el grado de desarrollo y las consecuencias de este innovador diálogo interregional sobre violencia sexual (VI).

Un apunte final. Esta contribución se suma a una línea de investigación conjunta sobre el tratamiento de la violencia sexual en el Derecho Internacional contemporáneo que las dos autoras venimos desarrollando desde hace una década, con una metodología de trabajo de reflexión por dos mentes y escritura a cuatro manos. En este caso, Magdalena M. Martín se ha encargado de los epígrafes II y V $(1,2,3)$ y a Isabel Lirola corresponde la redacción del III, IV y V (4). Ambas hemos redactado conjuntamente la introducción y las conclusiones. Abordamos así una faceta de la violencia sexual que hasta ahora no habíamos explorado, en consonancia con la sugerencia que hace algún tiempo nos formuló nuestra común amiga la jueza Elisabeth Odio Benito, y que además había permanecido prácticamente inédita en la doctrina internacionalista.

\section{El papel del TEDH y de la CIDH en el tratamiento de la violencia sexual en el sistema de justicia penal internacional}

En las páginas precedentes hemos avanzado que la sociedad internacional posmoderna se caracteriza por su judicialización, tendencia que está íntimamente vinculada con dos fenómenos emergentes. Por una parte, la expansión normativa del ordenamiento jurídico internacional y la subsiguiente aparición de regímenes especiales, sectores o ramas del Derecho Internacional, caso del Derecho Internacional de los Derechos Humamos y del Derecho Internacional Penal, que tienden a dotarse de sus propios órganos jurisdiccionales, tejiendo una red o sistema de tribunales internacionales descentralizado, puesto que entre ellos no existe jerarquía. Por otra parte, con la fragmentación del Derecho Internacional, ya que muchos de estos tribunales tienen competencias limitadas geográficamente y/o en razón de la materia, por lo que refuerzan el particularismo en detrimento de una concepción global del ordenamiento internacional ${ }^{13}$.

\footnotetext{
${ }^{13}$ La bibliografía sobre ambos aspectos que sirven de telón de fondo del presente trabajo es ya inabarcable, vid por todos las aportaciones de Antonio Cançado Trindade, La búsqueda de la realización de la justicia en la era de los Tribunales Internacionales, en Diálogo jurisprudencial en derechos humanos entre tribunales constitucionales y cortes internacionales: in memoriam Jorge Carpizo, generador incansable de diálogos, E. Ferrer Mac Gregor, A. Herrera García (coord.), 2013, pp. 1351-1412; The Construction of a Humanized International Law, Bryll, 3 vol., (2014), los dos 
Este es el telón de fondo de nuestro análisis, a partir del cual desarrollaremos aquellas cuestiones del diálogo jurisdiccional interregional que hemos consideramos más relevantes para evidenciar las coincidencias y las mutuas influencias surgidas en relación a la violencia sexual ${ }^{14}$. Nuestra premisa de partida consiste en que en la criminalización de la violencia sexual éste diálogo jurisdiccional, entendido como una influjo recíproco en virtud del cual la jurisprudencia de un tribunal fortalece expresa o tácitamente los argumentos del otro, reforzando su autoridad, es una manifestación novedosa de la primacía del orden público y las limitaciones al voluntarismo estatal en el marco de sus respectivas convenciones protectoras de los derechos humanos ${ }^{15}$. El foco de atención se centra pues en las similitudes y diferencias entre los dos tribunales, ya que ambas reflejan, a modo de espejo, la diversidad de intérpretes en la construcción de estándares constitucionales regionales protectores de los derechos humanos ${ }^{16}$. En este sentido, aunque a nuestro juicio las realidades europea y americana son radicalmente distintas en todas sus dimensiones (histórica, sociopolítica, jurídica y humana) los grandes desafíos que han de afrontar, entre los que sin duda se encuentra la violencia sexual, son muy similares, y las soluciones cada vez más convergentes, tanto en términos sustantivos como procesales ${ }^{17}$.

No obstante, antes de entrar en materia formularemos cuatro consideraciones en relación al papel del TEDH y de la CIDH en el tratamiento de la violencia sexual en el sistema de justicia penal internacional del todo necesarias para una comprensión holística de esta compleja cuestión.

En primer lugar, que la persecución de la violencia sexual corresponde a una pluralidad de tribunales que conforman lo que hemos dado en llamar el sistema de justicia penal internacional, fruto de la fertilización cruzada de tres ramas o sectores normativos: el Derecho Internacional Penal, al que corresponde

primeros volúmenes recogen sus opiniones individuales como juez en la CIDH y el TIJ en el periodo 1991-2013 y el tercero desde 2013 a 2015.

${ }^{14}$ Andreé Viana Garcés, "Sistemas Europeo y Americano de Protección de Derechos Humanos. Coincidencias, fraccionamientos temporales y mutuas influencias", en Miguel A. Revenga Sánchez y Andreé Viana Garcés (eds), Tendencias jurisdiccionales de la Corte Interamericana y el Tribunal Europeo de Derechos Humanos, Tirant lo Blanch, 2008, pp. 17-70.

${ }^{15}$ Laura Alicia Camarillo Govea, "Convergencias y divergencias entre los sistemas europeo e interamericano de Derechos Humanos", 37 Revista Prolegómenos (2016), pp. 67-84.

${ }^{16}$ Francisco Javier Ansuátegui Roig, op. cit. pp. 24-41; Bruno Rodríguez Reveginno, "Espacios de dialogo entre la Corte Interamericana de Derechos Humanos y el Tribunal Europeo de Derechos Humanos", 7 Revista Internacional de Derechos Humanos (2017), pp. 15-37; Eduardo Ferrer McGregor, "What do we mean when we talk about judicial dialogue?: Reflections of a judge of the Inter-American Court of Human Rights", 30 Harvard Human Rights Journal (2017), pp. 89-129.

17 Oscar Parra Vera, "Algunos aspectos procesales y sustantivos de los diálogos recientes entre la Corte Interamericana de Derechos Humanos y el Tribunal Europeo de Derechos Humanos", en Pablo Santolaya/I. Wences (coords.), La América de los Derechos, Centro de Estudios Políticos y Constitucionales, 2016, pp. 565-606; Laurence Burgorgue-Larse., Nicolás Montoya Céspedes, "El diálogo judicial entre la Corte Interamericana y la Corte Europea de Derechos Humanos", en Protección Multinivel de Derechos Humanos. Manual, G. Rodrigo/R. Ureña/A Torres (coords.), 2013. 
la determinación de la responsabilidad penal individual y tipificación de los crímenes violencia sexual; el Derecho Internacional de los Derechos Humanos, que en esta materia establece el deber estatal de investigación y sanción, así como una especial protección para las víctimas; y el Derecho Internacional Humanitario, en cuyo marco se consolida la prohibición de la violencia sexual en situaciones de conflicto. La naturaleza y competencia de los tribunales que componen dicho sistema es bien distinta, pero su jurisdicción es concurrente, en la medida en que los Tribunales de Derechos Humamos y en particular la CIDH y el TEDH comparten un objetivo común con el resto de tribunales: la lucha contra la impunidad.

En segundo lugar, partiendo de la ya referida autonomía de los tribunales internacionales, y de la inexistencia de jerarquía, es perfectamente plausible la diversidad de criterios jurisprudenciales en relación a la violencia sexual ente la Corte Interamericana y Tribunal Europeo, al igual que sucede con los Tribunales ad hoc y la Corte Penal Internacional objeto de nuestros trabajos previos. De hecho, tanto el Tribunal Penal Internacional para la ex Yugoslavia como la Corte Penal Internacional no han dudado en afirmar sin ambages $\mathrm{su}$ total independencia respecto de los restantes órganos jurisdiccionales internacionales, incluyendo a la CIJ, que es el intérprete máximo del ordenamiento internacional genera ${ }^{18}$. En parecidos términos se ha pronunciado también el TEDH, insistiendo reiteradamente en la "especificidad del Convenio Europeo como tratado especial de derechos humanos" "19. La tendencia hacía una interpretación literal o restrictiva que atiende a la letra del Convenio Europeo y a la voluntad de los Estados miembros, frente a una lectura más amplia y teleológica de la Convención Interamericana, han llevado a calificar prima facie al TEDH como un tribunal tímido frente a la audacia de la CIDH, si bien un estudio en profundidad de los respectivos contextos, así como del alcance de sus fallos en los derechos internos, permite concluir que estos calificativos son inapropiados, ya que la labor desarrollada y los efectos de la jurisprudencia de los dos tribunales no difieren en demasía ${ }^{20}$.

\footnotetext{
18 Sentencia Prosecutor contra DuskoTadic, Caso Nº IT-94-A-1, 1999, párrs. 115 y 137. 1999. En ella el TPIY se aparta de la jurisprudencia previa de la CIJ respecto a la responsabilidad internacional estatal por los actos cometidos por sus fuerzas militares, desplegada en la sentencias sobre la actividades militares y paramilitares en y contra Nicaragua (1986) y la Aplicación de la Convención sobre prevención y sanción del delito de Genocidio (Bosnia y Herzegovina contra Serbia y Montenegro, 2007). Con posterioridad la Corte Penal Internacional ha profundizado en la brecha con la CIJ, al seguir la senda marcada por el TPIY en la sentencia "Prosecutor c. Thomas Lubanga" de 14 de marzo de 2002, respecto al "test de control" aplicable para desestimar la responsabilidad del Estado por los crímenes cometidos por el acusado. Al respecto Kai AMBOS (et altri), Análisis de la primera sentencia de la Corte Penal Internacional: el caso Lubanga, Fundación Konrad Adenauer, 2014, p. 469.

19 TEDH, Caso Loizidou contra Turquía, sentencia de 23 de marzo de 1995. En ella el TEDH discrepa de la libertad para formular reservas a los tratados que defendían en su jurisprudencia previa tanto la Corte Permanente como la CIJ.

${ }^{20}$ Kai Ambos, María Laura Bohm, "Tribunal Europeo de Derechos Humanos y Corte Interamericana
} 
En tercer lugar, como consecuencia de dicha autonomía e independencia, la jurisprudencia internacional sobre violencia sexual es diferente o incluso divergente, puesto que de ella se ocupan simultáneamente los tribunales penales ad hoc y la Corte Penal Internacional en el marco del Derecho Internacional Penal; los tribunales de Derechos Humanos en el marco del Derecho Internacional de los Derechos Humanos. Y por último, también tribunales propios de Organizaciones Internacionales sui generis, caso de la UE. Así pues, coexisten al menos tres tipos de órganos jurisdiccionales internacionales, con sus respectivos modos de pensamiento jurídico propio: el de los Tribunales Penales ("Criminal law thinking"), el de los Tribunales de Derechos Humanos ("Human Rights law thinking"), y el del TJUE ("European law thinking"), que difieren sobre el modelo de justicia (punitiva, restaurativa, europea) que debe primar en el enjuiciamiento y sanción de los delitos y crímenes internacionales en general y en los de violencia sexual en particular.

Por último pero no menos importante, si bien esta pluralidad de órganos coadyuvan en la lucha contra la impunidad, su marco normativo competencial (ratione materia, ratione persona y ratione temporis) y el contexto en el que ejercen su labor son sustancialmente diferentes. Sin entrar en un análisis pormenorizado, que excedería el marco de la presente contribución, hay que resaltar que mientras que los tribunales penales internacionales dilucidan la responsabilidad penal individual por la comisión de crímenes internacionales, tanto la CIDH como el TEDH determinan la responsabilidad internacional de los Estados como sujetos de Derecho Internacional cuando se hayan producido vulneraciones de los derechos humanos incluidas aquellas que, por su extrema gravedad, merezcan ser calificadas de crímenes internacionales.

\section{Una aproximación empírica: una jurisprudencia temática que a priori se ajusta a los patrones de un diálogo interregional "unidireccional"}

La jurisprudencia de la TEDH y de la CIDH en materia de violencia sexual puede ser objeto de un primer examen tomando en consideración los parámetros cuantitativos y cualitativos que se utilizan habitualmente para el análisis del diálogo interregional. De acuerdo con el primero, una vez localizadas las sentencias de ambos tribunales cuyos supuestos de hecho incluyan la comisión de actos de violencia sexual que hayan dado lugar a la violación de los derechos protegidos en los respectivos ámbitos de jurisdicción, se toman en consideración las citas reciprocas. Esta tarea, aparentemente sencilla, no resulta tan fácil como

de Derechos Humanos. ¿Tribunal tímido vs. tribunal audaz?, en Sistema Interamericano de Protección de los Derechos Humanos y Derecho Penal Internacional- Tomo II, Montevideo: Fundación Konrad Adenhauer, Universidad de Gottingen, 2011, pp. 43-69.

Araucaria. Revista Iberoamericana de Filosofia, Política, Humanidades y Relaciones Internacionales, año 20, $\mathrm{n}^{\circ} 40$ Segundo semestre de 2018. Pp. 511-575. ISSN 1575-6823 e-ISSN 2340-2199 doi: 10.12795/araucaria.2018.i40.23 
pudiera parecer en principio, debido a las dificultades técnicas que suscita el uso de las respectivas bases de datos, que no permiten buscar referencias cruzadas, salvo que se conozcan previamente las sentencias en las que éstas se encuentran. Eso explica posibles inexactitudes en los datos que a continuación se exponen que, en todo caso, en nada alteran las conclusiones alcanzadas.

Hecha esta salvedad, de las sentencias localizadas en el caso de la $\mathrm{CIDH}$ que se refieren a actos de violencia sexual ${ }^{21}$, se constata que contienen menciones expresas a decisiones del TEDH en este mismo ámbito más de la $\operatorname{mitad}^{22}$. En cambio, en ninguna de las sentencias del TEDH que responden a estos mismos criterios $^{23}$, se han encontrado referencias expresas a decisiones de la CIDH en materia de violencia sexual. Sorprendentemente, tales referencias sólo aparecen en tres pronunciamientos relativos a casos de violencia de género (doméstica) ${ }^{24}$, sin presencia explicita de violencia sexual, y en una sentencia sobre crímenes de guerra ${ }^{25}$. Por tanto, la utilización de un parámetro meramente cuantitativo de

21 CIDH, Caso Campo Algodonero contra México, Sentencia de 16 de Noviembre de 2009 (Excepción Preliminar, Fondo, Reparaciones Y Costas); Caso Penal Miguel Castro contra Perú (2006); Caso Rosendo Cantú contra Méjico, Sentencia de 31 de agosto de 2010, (Excepción Preliminar, Fondo, Reparaciones y Costas); Caso Masacre Rio Negro contra Guatemala, Sentencia de 4 de septiembre de 2012 (Excepción Preliminar, Fondo, Reparaciones y Costas); Caso Masacres de El Mozote y lugares aledaños contra El Salvador, Sentencia de 25 de octubre de 2012 (Fondo, Reparaciones y Costas); Caso J. contra Perú Sentencia de 27 de noviembre de 2013 (Excepción Preliminar, Fondo, Reparaciones y Costas); Caso Veliz Franco y otros contra Nicaragua, Sentencia de 19 de Mayo de 2014 (Excepciones Preliminares, Fondo, Reparaciones y Costas); Caso Favela Nova Brasilia contra Brasil, Sentencia de 16 de febrero de 2017 (Excepciones Preliminares, Fondo, Reparaciones y Costas); Caso V.R.P., V.P.C. y otros contra Nicaragua, Sentencia de 8 de marzo de 2018 (Excepciones Preliminares, Fondo, Reparaciones y Costas)

22 CIDH, Caso Masacre Plan de Sánchez contra Guatemala Penal, Sentencia de 29 de abril de 2004 (Fondo); Caso Campo Algodonero contra Méjico (2009); Caso Penal Miguel Castro contra Perú (2006); Caso Masacre Dos Erres contra Guatemala (2009); Caso Fernández Ortega y otros Vs. Méjico, Sentencia de 30 de agosto de 2010 (Excepción Preliminar, Fondo, Reparaciones y Costas); Caso Rosendo Cantú contra Méjico (2010); Caso Masacre Rio Negro contra Guatemala (2012); Caso Masacre El Mozote contra El Salvador (2012); Caso J. contra Perú (2013); Caso Espinosa contra Perú (2014); Caso Veliz Franco contra Nicaragua (2014); Caso Favela Nova Brasilia contra Brasil (2017); Caso V.R.P. contra Nicaragua (2018).

23 TEDH, Caso X e Y contra Países Bajos. Sentencia de 26 de marzo de 1985; Caso Aydin contra Turquía. Sentencia de 25 de septiembre de 1997; Caso Aydin contra Turquía. Sentencia de 25 de septiembre de 1997; Caso M.C. contra Bulgaria. Sentencia de 4 de diciembre de 2003; Caso Y.F contra Turquía. Sentencia de 22 de julio de 2003; Caso Menesheva contra Rusia. Sentencia de 9 de marzo de 2006; Caso Juhnkev contra Turquía. Sentencia de 13 de mayo de 2008; Caso Maslova contra Rusia. Sentencia de 24 de enero de 2008; Caso Salmanoglu contra Turquía. Sentencia de 17 de marzo de 2009; Caso Rantsev contra Chipre y Rusia. Sentencia de 7 de junio de 2010; Caso Yazgül Yilmaz contra Turquía (2011); Sentencia de 1 de febrero de 2011; Caso P.M. contra Bulgaria. Sentencia de 24 de enero de 2012; Caso I.G. contra Moldavia. Sentencia de 15 de mayo de 2012; Caso D.J contra Croacia. Sentencia de 24 de julio 2012; Caso M. y otros contra Italia y Bulgaria. Sentencia de 1 de agosto de 2012; Caso O'Keeeffe contra Irlanda. Sentencia de 28 de enero de 2014; Caso M.A. contra Eslovenia. Sentencia de 23 de enero de 2014; Caso W. contra Eslovenia. Sentencia de 23 de enero de 2014; Caso S.Z. contra Bulgaria. Sentencia de 3 de marzo de 2015; Caso B.V. contra Bélgica. Sentencia de 2 de mayo de 2017; Caso S.M. contra Croacia. Sentencia de 19 de julio de 2018.

${ }^{24}$ Caso Bevacqua contra Bulgaria. Sentencia de 12 de junio de 2008; Caso Opuz contra Turquía. Sentencia de 9 de junio de 2009; Caso Valiuliene contra Lituania. Sentencia de 26 de marzo de 2013.

${ }^{25}$ Caso Maktouf y Damjanovic contra Bosnia. Sentencia de 18 de julio de 2013 
análisis sirve para situar la interacción de la jurisprudencia de ambos Tribunales en esta materia dentro de uno de los patrones habituales del diálogo interregional ya anticipado: el de un diálogo de carácter unidireccional, conforme al cual es la $\mathrm{CIDH}$ la que sigue a la jurisprudencia del TEDH, pero no a la inversa ${ }^{26}$.

Pasando ahora en segundo lugar a utilizar un paramento cualitativo, se trata de determinar el objetivo con el que cada uno de estos Tribunales recurre a la jurisprudencia del otro, finalidad que se concluye del lugar en que la cita se sitúe en la sentencia. El examen de estas mismas sentencias, pone de manifiesto que la CIDH utiliza la referencia a la jurisprudencia del TEDH como elemento de legitimación de sus propias decisiones. Se confirma así otro de los patrones "típicos" del diálogo interregional que hace referencia a la utilización de la CIDH de la jurisprudencia del TEDH como "autoridad persuasiva" ${ }^{27}$. En estos mismos patrones típicos se sitúa la utilización por parte del TEDH de las decisiones de la CIDH para dar cuenta del Derecho Internacional existente ${ }^{28}$. Sin embargo, hay que matizar que, aun a pesar de la insignificancia de la muestra, también el TEDH cita dichas decisiones en el cuerpo de la sentencia a efectos de lo que se ha llamado "comparación confortativa o probatoria" 29 en relación a la utilización de conceptos y principios establecidos por la $\mathrm{CIDH}^{30}$.

Dentro de este mismo parámetro cuantitativo puede también valorarse si la cita se encuentra en el cuerpo de la sentencia o en votos particulares. Las citas de la CIDH a la jurisprudencia del TEDH se corresponden con la primera opción, que resulta congruente con el objetivo legitimador y de reforzamiento de sus propios argumentos con los que la CIDH las utiliza. En cambio, el hecho que de las cuatro sentencias del TEDH que contienen referencia a decisiones de la $\mathrm{CIDH}$, dos de ellas se encuentren en opiniones concurrentes emitidas por un juez de nacionalidad portuguesa ${ }^{31}$, nos lleva a concluir que el carácter bidireccional de diálogo es más fácil cuando concurren factores de afinidad, como podría ser en este caso la cultura jurídica.

${ }^{26}$ Kerstin Blome, "Wallflower or Essential Constituent? The Inter-American Court of Human Rights' Role in an Emerging International Judicial Human Rights System” en SGIR 7th Pan-European International Relations Conference, (Section 32: International Institutions, Global Politics, and Law Panel VIII: Towards a Global Network of Courts?) September 2010, p.14.

${ }^{27}$ Cf. Anne-Marie Slaughter, "A Typology of Transjudicial Communication” en University of Richmond Law Review, 1 (1994) p.106.

${ }^{28}$ Carla Zoethout,"The European Court of Human Rights and Transnational Judicial Dialogue. References To Foreign Law and the Quest for Justification”, Vienna J. on Int'l Const. L., 3 (2015), pp.403-404.

29 Terminología que tomamos de Groppi, Lecis Cocco-Ortu, op.cit., p.218.

${ }^{30}$ Caso Bevacqua contra Bulgaria (2008) citando al Caso Velásquez-Rodríguez contra Honduras (1988) para la fundamentación de los conceptos de diligencia debida y obligaciones positivas y caso Aydin contra Turquía (1997) en el que el Tribunal menciona las alegaciones presentadas por Amnistia Internacional citando la jurisprudencia de la $\mathrm{CIDH}$ sobre la categorización de la violación como tortura.

31 Opinión concurrente del juez Pinto de Alburqueque en los casos Valiuliene contra Lituania (2013); Maktouf y Damjanovic contra Bosnia (2013).

Araucaria. Revista Iberoamericana de Filosofia, Politica, Humanidades y Relaciones Internacionales, año 20, $\mathrm{n}^{\circ} 40$. Segundo semestre de 2018. Pp. 511-575. ISSN 1575-6823 e-ISSN 2340-2199 doi: 10.12795/araucaria.2018.i40.23 
En suma, en una primera aproximación de carácter formal destaca la total ausencia de referencias expresas a la jurisprudencia de la $\mathrm{CIDH}$ en las sentencias del TEDH en la que la violencia sexual es la causa de la violación de los derechos protegidos. Este dato sin duda condiciona y restringe el alcance de las conclusiones obtenidas mediante los parámetros cuantitativos y cualitativos de análisis empírico. Asumiendo unos márgenes de comparación más amplios de "violencia de género" en vez de únicamente de violencia sexual, el examen confirma que esta jurisprudencia temática se ajusta a los patrones habituales que caracterizan al diálogo birregional como un diálogo marcadamente unidireccional, en el que la incidencia de la jurisprudencia del TEDH sobre la de la CIDH es comparativamente mucho mayor. En cambio, la inclusión expresa de las aportaciones de la CIDH en las decisiones del TEDH, aunque relevante, sería muy escasa y condicionada, entre otros elementos, por factores de afinidad cultural.

\section{Una aproximación contextual: elementos fácticos particulares y comunes en los casos de violencia sexual ante el TEDH y la CIDH}

La jurisprudencia de la TEDH y la CIDH sobre violencia sexual puede ser objeto de una segunda aproximación de carácter contextual. Esta aproximación es muy relevante porque desde la óptica más amplia de la violencia contra la mujer se trata de un ámbito en el que el diálogo birregional no se evidencia sólo de manera explícita, sino que se pone de manifiesto a través de cambios estructurales y la evolución paralela de los mismos conceptos en ambos sistemas $^{32}$.

Desde esta perspectiva, se observa una primera coincidencia en el tiempo. Así, salvo las sentencias en los casos X y Y contra Países Bajos (1985) y Aydin contra Turquía (1997) ${ }^{33}$, el grueso de la jurisprudencia sobre violencia sexual de ambos Tribunales se ha desarrollado a partir del inicio del presente siglo. Esta coincidencia temporal no es casual. Primeramente, se debe a razones consustanciales al funcionamiento de los dos sistemas de protección regional. Por lo que respecta al americano, se ha señalado la reticencia de la Comisión Interamericana a remitir demandas individuales sobre cuestiones de género a la CIDH, pese a su propio activismo en la materia ${ }^{34}$. En relación al europeo, este momento coincide con la entrada en vigor del Protocolo 11 al Convenio de Roma y sus reformas, sin que conste una particular actividad de la Comisión

\footnotetext{
${ }^{32}$ Camille Jacquemin, Gender Violence" in the Case-Law of the European Court of Human Rights, Master dissertation, Faculty of Law, Ghent, University of Ghent Academic year 2012-13.

33 Esta decisión del TEDH, por su proyección birregional, podría calificarse de "sentencia fundacional siguiendo la terminología que utiliza Bustamante Arango, op.cit., p.469.

34 Clérico/Novelli, op.cit., pp.16-17.
} 
europea de Derechos Humanos (ComisiónEDH) en relación a casos de violencia sexual, salvo alguna escasísima excepción ${ }^{35}$.

También hay que tener en cuenta los cambios acaecidos en Europa y América Latina. Durante este periodo, junto a la violencia sexual derivada de la situación sistémica de discriminación de las mujeres en América Latina, se hacen visibles ante la CIDH las violaciones generalizadas y sistemáticas de derechos humanos acaecidas en el marco de los conflictos en Guatemala, El Salvador o Perú, en los que la violencia sexual generalizada contra las mujeres se utilizó de forma sistemática como instrumento de represión. A su vez, llegan ante el TEDH numerosos casos de violencia sexual generados en las nuevas democracias en transición de los países de la Europa Central y Oriental, a la vez que los procedentes de otros dos Estados miembros del Consejo de Europa, Rusia y Turquía, con un particular historial de debilidad en la protección de los derechos humanos.

Así, la lectura positiva a esta emergencia de la violencia sexual y la atención a sus víctimas estriba en el empoderamiento de colectivos vulnerables y marginalizados que antes permanecían "invisibles y alijados" de los mecanismos de protección de derechos humanos regionales ${ }^{36}$. Sin embargo, no se puede obviar que concurre, como señala Brysk, con una lectura negativa, relacionada con una creciente inseguridad de las mujeres en el mundo, a pesar de las supuestas pautas modernizadoras y equitativas de la globalización. En esta línea, como apunta esta misma autora, los regímenes autoritarios liberalizadores y las democracias transicionales presentan índices mayores de delincuencia y violencia debido, entre otros factores, a la fragmentación e incertidumbre que experimentan las estructuras históricas de autoridad y coerción ${ }^{37}$.

En segundo lugar, se observa también una serie de similitudes en cuanto a las víctimas y los autores de la violencia sexual en la jurisprudencia de ambos Tribunales.

Por lo que respecta a las víctimas, un elemento clave de coincidencia es que la violencia sexual se ejerce como "violencia de género". Sin perjuicio de que también se utilice contra los hombres, aspecto merecedor de un examen individualizado sobre el que volveremos sucintamente ${ }^{38}$, se emplea fundamentalmente contra las mujeres por su condición de tales y por la situación de discriminación en la que se encuentran. Sin embargo, esta dimensión de género de la violencia sexual sólo se explicita por la $\mathrm{CIDH}$,

\footnotetext{
${ }^{35}$ Caso Harron y Alayo contra Suecia, Decisión de 7de marzo de 1996.

${ }^{36}$ Bruno Rodríguez Reveggino, op. cit, p.28.

37 Alison Brysk, "Introducción: violencia de género y relaciones internacionales" en Revista CIDOB d'Afers Internacionals, 117 (2017), pp.18-19.

38 Patricia Tarre Moser/Salvador Leyva Morelos-Zaragoza, "Violencia sexual contra el hombre: avance jurisprudencial de la Corte Interamericana de los Derechos Humanos" en Revista Internacional de Derechos Humanos, 5 (2015), pp. 69-90, y Clare McGlynn, "Rape, Torture and the European Convention on Human Rights” en International and Comparative Law Quarterly, 3 (2009), pp. 565-595.
} 
que ha señalado expresamente que la violencia sexual por ser una "violencia dirigida contra una mujer por ser mujer" o "que afecta a la mujer de manera desproporcionada", es una forma de discriminación en contra de la mujer ${ }^{39}$. La discriminación estructural que alimenta la violencia sexual puede derivarse de una circunstancia concreta, caso de las mujeres que pertenecen a comunidades indígenas, tal y como se desprende de casos ante la $\mathrm{CIDH}^{40}, \mathrm{o}$, como podría inferirse en algunos asuntos presentados ante el TEDH, por su pertenencia a minorías, por ejemplo la kurda o la romaní ${ }^{41}$.

Sin embargo, la utilización de la violencia sexual se deriva fundamentalmente de lo que podría calificarse de situaciones "sistémicas" de discriminación de la mujer. También en este punto la CIDH es totalmente explicita, como evidencia el que, por ejemplo, constate la existencia de una "cultura de discriminación de la mujer" en Méjico ${ }^{42}$ o "la invisibilidad de la violencia contra la mujer" en Guatemala ${ }^{43}$. En cambio, el TEDH sólo se refiere a la discriminación contra la mujer en el caso de la violencia doméstica ${ }^{44}$, pero no específicamente a propósito de la violencia sexual, aunque ésta pueda concluirse de las condenas a Estados parte como Bulgaria o Eslovenia por haber incumplido reiteradamente la obligación de investigar y sancionar en casos de violencia sexual ${ }^{45}$. Es decir, como se ha señalado, la falta del cumplimiento por las autoridades estatales del deber de diligencia ante la violencia sexual, al afectar principalmente a las mujeres, supone una situación discriminatoria ${ }^{46}$. De hecho, la ausencia de esta perspectiva en el tratamiento de la violencia sexual fuera del ámbito doméstico por el TEDH puede deberse, entre otras, a razones procesales, ya que el artículo 14 del Convenio de Roma requiere que la demandante pruebe la existencia de un comportamiento discriminatorio

${ }^{39}$ Caso Veliz Franco y otros contra Nicaragua (2014), párr.207 citando al Caso Opuz contra Turquía (2009) párr. 200.

${ }^{40}$ CIDH, Caso Masacre Plan de Sánchez contra Guatemala Penal (2004); Caso Masacre Dos Erres contra Guatemala (2009); Caso Fernández Ortega contra Méjico (2010); Caso Rosendo Cantú contra Méjico (2010); Caso Masacre Rio Negro contra Guatemala (2012); Caso Masacre El Mozote contra El salvador (2012) y María Teresa Ponte Iglesias, "Protección de las mujeres indígenas frente a la violencia y acceso a la justicia: una visión desde el Derecho Internacional" (en Alexandra Tomaselli, Marzia Rosti, Roberto Cammarata \& Chiara Scardozzi, eds.: Desafios de los pueblos indígenas en su participación política y socio-económica: recursos naturales, género, educación y propiedad intelectual, Bolzano, Eurac Research, 2017), pp. 302-307.

${ }^{41}$ TEDH, Caso Aydin contra Turquía (1997); Caso Salmanoglu contra Turquía (2009); Caso M. v. Italia y Bulgaria (2012).

${ }^{42}$ CIDH, Caso Campo algodonero contra Méjico (2009), párr. 398

${ }^{43}$ CIDH, Caso Veliz Franco y otros contra Nicaragua (2014), párr.67.

44 TEDH, Caso Opuz contra Turquía (2009); Caso A. contra Croacia. Sentencia de 14 de octubre de 2010; Caso Rumor contra Italia. Sentencia de 27 de mayo de 2014; Caso Halime Kiliç contra Turquía. Sentencia de 28 de junio de 2016; Caso Talpis contra Italia. Sentencia de 2 de marzo de 2017; Caso Bălşan contra Rumania. Sentencia de 23 de mayo de 2017.

${ }^{45}$ TEDH, S.Z. contra Bulgaria (2015); M.A. contra Eslovenia (2014)

${ }^{46}$ Ivana Radačić, "Rape Cases in the Jurisprudence of the European Court of Human Rights: Defining Rape and Determining the Scope of the State's Obligations" en European Human Rights Law Review, (2008), pp. 5 9-10. 
atribuible a las autoridades. Por eso, sería conveniente que dicho precepto se aplicara a todo tipo de violencia sexual, porque así el TEDH podría abordar la violencia contra la mujer en su totalidad ${ }^{47}$, como en cambio hace la $\mathrm{CIDH}$, al considerar que el deber de no discriminación sí está contenido en el art. 1.1 del Pacto de San José.

En todo caso, llama la atención el altísimo porcentaje de víctimas de violencia sexual que son menores, tanto en los casos que han llegado a la $\mathrm{CIDH}$ como al $\mathrm{TEDH}^{48}$. Ambos coinciden en su especial vulnerabilidad y en la necesidad de asegurarles una protección especial y efectiva frente a la violencia sexual. Tal protección se traduce en una reducción de los márgenes de apreciación que tienen los Estados en relación al cumplimiento de sus obligaciones y en una intensificación del deber de diligencia debida ${ }^{49}$.

De la misma manera, es posible establecer puntos de conexión en relación a los autores de la violencia sexual. Por lo que respecta a la violencia perpetrada por agentes estatales, se constata la coincidencia fáctica en relación a la violencia sexual contra personas detenidas, bien en el marco de los interrogatorios policiales o a través de la realización de los llamados “exámenes ginecológicos" a mujeres en prisiones o en centros policiales, en Perú, Rusia y Turquía ${ }^{50}$. Asimismo en el continente americano destaca la utilización de la violencia sexual por las fuerzas y cuerpos de seguridad del Estado, bien en el marco de operaciones militares (Perú, Guatemala y El Salvador) ${ }^{51}$, policiales (Brasil) $^{52}$, así como la "violencia institucional castrense" en México ${ }^{53}$.

Se observa además como nota común que las mujeres están particularmente desprotegidas frente a la violencia sexual de los particulares, ya pertenezcan a su círculo personal más próximo, por ser miembros de su familia, parejas o incluso

${ }^{47}$ Madeleine Eklund, Violence Against Women as a Violation of the European Convention On Human Rights: Due Diligence and State Responsibility for Violence against Women by Private Actors (Bachelor's thesis), Örebro, Örebro Univertitet, 2016, pp.29-30.

${ }^{48}$ En relación con la CIDH, caso Masacre Plan de Sánchez contra Guatemala Penal (2004); Caso Masacre Dos Erres contra Guatemala (2009); Caso Masacre Rio Negro contra Guatemala (2012); Caso Veliz Franco y otros contra Nicaragua (2014); Caso V.R.P. contra Nicaragua (2018). Por lo que respecta al TEDH, Caso X e Y contra Países Bajos (1985); Caso Aydin contra Turquía (1997); Caso M.C contra Bulgaria (2003); Caso Yazgül Yilmaz contra Turquía (2011); Caso I.G. contra Moldavia (2012); Caso M. contra Italia y Bulgaria (2012); Caso O'Keeeffe contra Irlanda (2014); Caso A, B and $\mathrm{C}$ contra Letonia. Sentencia de 31 de marzo de 2016.

${ }^{49}$ CIDH, Caso Veliz Franco y otros contra Guatemala (2014), párr. 141; Caso V.R.P. contra Nicaragua (2018), párr.285; Caso C.A.S. y C.S. contra Rumania, párr.71.

50 TEDH, Caso Y.F contra Turquía (2003), Caso Juhnkev contra Turquía (2008), Caso Yazgül Yilmaz contra Turquía (2011); Caso Meneshevav contra Rusia (2000); Caso Maslova contra Rusia (2008).

51 CIDH, Caso Masacre Plan de Sánchez contra Guatemala Penal (2004); Caso Penal Miguel Castro contra Perú (2006), Caso Masacre Dos Erres contra Guatemala (2009); Caso Masacre Rio Negro contra Guatemala (2012); Caso Masacre El Mozote contra El salvador (2012); J. contra Perú (2013); Caso Espinosa contra Perú (2014).

${ }^{52}$ CIDH, Caso Favela Nova Brasilia contra Brasil (2017)

53 CIDH, Caso Fernández Ortega y otros contra México (2010); Caso Rosendo Cantú contra Méjico (2010).

Araucaria. Revista Iberoamericana de Filosofia, Política, Humanidades y Relaciones Internacionales, año 20, $\mathrm{n}^{\circ} 40$. Segundo semestre de 2018. Pp. 511-575. ISSN 1575-6823 e-ISSN 2340-2199 doi: 10.12795/araucaria.2018.i40.23 
compañeros de trabajo, o ya carezcan de conexión personal con la víctima. No obstante, por el momento el TEDH ha conocido de más casos de violencia sexual cuyos perpetradores son particulares, frente a los que han llegado a la CIDH. Este dato podría apuntar a que en las sociedades americanas subsiste una mayor permisibilidad de la violencia sexual contra las mujeres, pese a los esfuerzos institucionales y el discurso político. En todo caso, se constata un diálogo entre ambos Tribunales en el que el TEDH utiliza la construcción llevada a cabo por la Comisión Interamericana y la CIDH en relación al deber de diligencia debida del Estado, si bien únicamente en el ámbito de la violencia doméstica ${ }^{54}$.

En suma, a pesar de las indudables diferencias contextuales en el que desarrollan su labor, destacan las similitudes fácticas existentes entre los casos que llegan a ambos Tribunales. Estas conexiones se predican tanto sobre las victimas como los victimarios, y resultan especialmente relevantes para plantear un diálogo birregional en términos estrictamente sustantivos, en la medida en que sirven de apoyo y explican la interacción de los enfoques y principios que cada uno de ellos aplica.

\section{Una aproximación sustantiva: la problemática conceptualización de los crímenes de violencia sexual por la CIDH y el TEDH}

En la medida en que como hemos reseñado, ni la CIDH ni el TEDH son tribunales penales internacionales, el mero hecho de que ambos órganos se ocupen de la violaciones de derechos humanos de índole sexual, y que además califiquen alguna de ellas como crímenes internacionales con el propósito de determinar el alcance de la obligación convencional de investigación y sanción asumida por los Estados parte (actualmente 47 en el CEDH y 22 en la Convención Interamericana), ha suscitado no pocas dificultades. No procede aquí ni ahora profundizar en el análisis del concepto y característica de los crímenes internacionales en general, ni las particularidades de los de violencia sexual, pero antes de examinar la problemática de su conceptualización en la jurisprudencia de los dos tribunales es preciso realizar algunas reflexiones teóricas.

Primero, que a los efectos que nos interesan, las violaciones de los derechos humanos de índole sexual que superen un umbral de sistematicidad y extrema gravedad podrán ser calificadas por ambos tribunales como crímenes de violencia sexual ${ }^{55}$. Sin embargo, el diferente contexto socio político y la

\footnotetext{
54 Lee Hasselbacher, "State Obligations Regarding Domestic Violence: The European Court of Human Rights, Due Diligence, and International. Legal Minimums of Protection" en Northwestern Journal of International Human Rights, 2 (2010), pp.190-215

55 Yennesit Palacios Valencia, "Tribunales Internacionales de Protección de Derechos Humanos en 
situación regional en la que operan la CIDH y el TEDH comporta un elemento diferenciador, ya que como hemos expuesto en el final del siglo XX y comienzos del XXI se han producido vulneraciones masivas y a gran escala de los derechos humanos en el marco de transiciones democráticas y/o conflictos armados en el continente americano ${ }^{56}$, incluyendo la violencia sexual como arma de guerra o como crimen de lesa humanidad, mientras que en el caso de la "gran Europa" los procesos transicionales y las guerras han sido más limitados tanto en el tiempo como en el espacio, registrándose violaciones graves de los derechos humanos e incluso crímenes internacionales, pero con un menor recurso sistemático a la violencia sexual. A ello hay que añadir que el mismo concepto de justicia transicional es ajeno a la actividad política y jurisdiccional del Consejo de Europa $^{57}$. En todo caso, los dos tribunales serían competentes para determinar la responsabilidad estatal por violaciones de sus respectivas convenciones de derechos humanos, incluidas aquellas que merezcan la calificación de crímenes internacionales, "sin que ello implique, de ningún modo, una imputación de un delito a persona natural alguna" 58 .

Segundo, que la prohibición de la comisión de crímenes internacionales, incluidos los de violencia sexual, constituye una norma de ius cogens que genera obligaciones exigibles a todos los sujetos internacionales, por lo que los efectos y las consecuencias de la responsabilidad estatal son mayores que las de un ilícito común. En tanto que derecho imperativo, la CIDH y el TEDH han reconocido que los crímenes internacionales son imprescriptibles, característica que, como después tendremos ocasión de comprobar, resulta determinante en contextos de justicia transicional y es el parámetro de validez última de las leyes internas de amnistía o punto final ${ }^{59}$. La imprescriptibilidad está consagrada convencionalmente a nivel universal en la Convención sobre la Imprescriptibilidad de los Crímenes de Guerra y de Lesa Humanidad, adoptada por la Asamblea General de las Naciones Unidas en la Resolución 2391 (xxii) de 1968, que tendría un efecto cristalizador, ya que codificaría una norma consuetudinaria preexistente, conforme a la teoría de interacción en su día

caso de crímenes internacionales", 2 REcorDIP, (2013), pp. 1-33, disponible en https://revistas.unc. edu.ar/index.php/recordip/article/view/6388.

${ }^{56}$ Javier Chinchón Álvarez, Derecho Internacional y transiciones a la democracia y la paz: hacia un modelo para el castigo de los crimenes pasados en la experiencia iberoamericana, Parthenon, 2007.

57 James A. Sweeney, J.A., The European Court of Human Rights in the Post-Cold War Era. Universality in transition, Routledge, 2013, p. 25 y ss.

58 CIDH, Caso Manuel Cepeda Vargas Vs. Colombia, Excepciones Preliminares, Fondo y Reparaciones. Sentencia de 26 de mayo de 2010.

59 Javier Dondé Matute., "El concepto de impunidad: leyes de amnistía y otras formas estudiadas por la Corte Interamericana de Derechos Humanos", en Sistema Interamericano de protección de los derechos humanos y Derecho Penal Internacional, Gisela Elsner (ed.), Grupo Latinoamericano de Estudio sobre Derecho Penal Internacional, Fundación K. Adenauer-Stiftung, 2010, pp. 263-295.

Araucaria. Revista Iberoamericana de Filosofia, Politica, Humanidades y Relaciones Internacionales, año 20, ${ }^{\circ} 40$. Segundo semestre de 2018. Pp. 511-575. ISSN 1575-6823 e-ISSN 2340-2199 doi: 10.12795/araucaria.2018.i40.23 
expuesta por Jiménez de Aréchaga ${ }^{60}$. De ello da fe su reiteración posterior en el artículo 29 del Estatuto de Roma. Idéntico reconocimiento encontramos en los dos marcos regionales, europeo y americano, en la Convención Europea sobre la Imprescriptibilidad de los Crímenes contra la humanidad y de los Crímenes de Guerra, adoptada por el Consejo de Europa el 25 de enero de 1974, y en el art. VII de la Convención Interamericana sobre Desaparición Forzada de Personas de 9 de junio de 1994.

Tercero, que a juicio de la CIDH y del TEDH la violencia sexual puede generar tanto la responsabilidad internacional de los Estados como la responsabilidad penal internacional de las personas físicas, pero ésta no sería objeto de su competencia, sino que se sustanciará ante los tribunales penales pertinentes del sistema de justicia penal internacional.

Y cuarto, que en el caso de la violencia sexual, tal y como hemos expuesto de manera detallada en nuestros trabajos previos, el bien jurídico protegido adquiere una especial relevancia, puesto que presenta una doble dimensión, individual/privada y colectiva/pública ${ }^{61}$ porque como corroboraremos a continuación, no solo vulnera la integridad física y psíquica de las víctimas, sino que también atenta contra intereses colectivo y comunitarios y en el caso de los crímenes internacionales, supone una amenaza a la paz y la seguridad ${ }^{62}$.

\subsection{Debates comunes en la investigación y sanción de la violencia sexual por la CIDH y el TEDH}

Una vez formuladas las anteriores reflexiones, necesarias para comprender el marco teórico del que partimos, examinaremos los problemas que su conceptualización comporta a la luz de la jurisprudencia de ambos tribunales, teniendo siempre presente el diálogo que ambos han entablado. A nuestro juicio el enjuiciamiento por la CIDH y por el TEDH de la violencia sexual

${ }^{60}$ Eduardo Jiménez de Aréchaga, E., "La costumbre como fuente del Derecho Internacional", en Estudios de Derecho Internacional. Homenaje al Profesor Miaja de la Muela, Tecnos, 1979, pp. 375-402; El Derecho Internacional Contemporáneo, Tecnos, 1980; Antonio Cassese, Five Masters of International Law: Conversations with RJ Dupuy, E. Jiménez de Aréchaga, R. Jennings. L. Henkin and O. Schachter, Oxford Hart Publishing, 2011.

${ }^{61}$ Magdalena M. Martín Martínez, Isabel Lirola Delgado., "Los crímenes de violencia sexual en el Derecho Internacional Humanitario, ICIP, Informes 8/2013, disponible en http://icip.gencat.cat/web/. content/continguts/publicacions/documents_i_informes/arxius/crimenes_de_violencia_sexual.pdf;

${ }^{62}$ Es por ello que los derechos internos definen los crímenes internacionales como delitos "pluriofensivos", ya que junto a bienes jurídicos concretos como la vida o la integridad de las víctimas, tutelan también intereses supraestatales. Así se reconoce expresamente, por ejemplo, en el título XXIV de nuestro Código Penal, bajo la rúbrica Delitos contra la comunidad internacional, arts. 605 a 616 quarter, que comprende cinco capítulos: delitos contra el derecho de gentes, delitos de genocidio, delitos de lesa humanidad, delitos contra las personas y bienes protegidos en caso de conflicto armado, disposiciones comunes y delito de piratería, vid. al respecto Alicia Gil Gil., "Delitos contra la comunidad internacional", en Comentarios prácticos al Código Penal, Manuel Gómez Tomillo (dir.), vol. 6. 2015, pp. 741 a 830.

Araucaria. Revista Iberoamericana de Filosofía, Política, Humanidades y Relaciones Internacionales, año 20, $\mathrm{n}^{\circ} 40$. Segundo semestre de 2018. Pp. 511-575. ISSN 1575-6823 e-ISSN 2340-2199 doi: 10.12795/araucaria.2018.i40.23 
suscita dudas en torno a cinco cuestiones cruciales, a saber: a) la categorización de la violencia sexual como crimen internacional y el principio de legalidad penal internacional; b) el alcance del deber estatal de investigar y sancionar la violencia sexual; c) criterios para la investigación de la violencia sexual en la labor llevada a cabo por ambos tribunales, y d) los límites y la tipología de las amnistías.

\section{A. La categorización de la violencia sexual como crimen internacional y el principio de legalidad penal internacional}

Por lo que a la primera dificultad de la que acabamos de enunciar se refiere, a la hora de satisfacer las exigencias del principio de legalidad penal internacional en la categorización de la violencia sexual como crimen internacional los dos tribunales se basan en la codificación previa llevada a cabo en tratados internacionales multilaterales y, en especial, en el Estatuto de Roma, instrumento en el que a partir del acervo previo de los tribunales ad hoc aparecen enunciados, de manera exhaustiva y pormenorizada, que actos son constitutivos de crímenes de violencia sexual de genocidio (art. 6), de lesa humanidad (art. 7) y de guerra (art. 8).

Así, el art. 7.1. g) del ER tipifica como crímenes de lesa humanidad, la violación, la esclavitud sexual, la prostitución forzada, el embarazo forzado, la esterilización forzada o "cualquier otra forma de violencia sexual de gravedad comparada". Idénticos crímenes están previstos en el art. 8, 2, b), xxii como crímenes de guerra, bajo el epígrafe "Otras violaciones graves de las leyes y usos aplicables en los conflictos armados internacionales", y en el art. 8, 2, d), vi), como "Otras violaciones graves de las leyes y los usos aplicables en los conflictos armados que no son de índole internacional". Como luego desarrollaremos, al igual que sucede en los tribunales penales, la violación es el crimen sexual por antonomasia en la jurisprudencia de la CIDH y el TEDH, que sin embargo también registra la variedad y multiplicación de otras formas de violencia sexual que desgraciadamente caracteriza a las sociedades internacional e internas.

Los actos de violencia sexual enumerados en el ER como crímenes de guerra y de lesa humanidad son idénticos, y además se definen de la misma manera. Esta identidad de contenidos asegura un mismo nivel de incriminación y sanción por parte de todos los tribunales encargados de su enjuiciamiento, inclusive la CIDH y el TEDH, resultando por tanto irrelevante a efectos de responsabilidad penal individual su inclusión en una u otra categoría. Se trata además de una lista abierta y sin carácter exhaustivo, puesto que en ambos casos se contempla la misma cláusula residual, que permite el enjuiciamiento de aquellas formas de abusos sexuales o de violencia sexual de igual gravedad que no estén expresamente previstas en el ER. 
Respecto al umbral de gravedad requerido para ser considerados crímenes, la jurisprudencia del TEDH y de la CIDH también ha hecho suyo el acervo de los tribunales penales, de manera que el genocidio y los crímenes de lesa humanidad conllevan el elemento de "política", esto es, que su comisión haya tenido lugar como parte de un ataque generalizado o sistemático contra la población civil. Por su parte, los crímenes de guerra presuponen el elemento "contextual" o de comisión en conflictos armados como parte de un plan o política, o de la comisión a gran escala de tales crímenes.

De esta manera, la CIDH en la sentencia de 26 de septiembre de 2006 en el conocido caso Almonacid ${ }^{63}$, consideró que la ejecución extrajudicial de la víctima era constitutiva de un crimen de lesa humanidad porque, lejos de suponer un ilícito aislado, formaba parte de un "ataque generalizado o sistemático contra sectores de la población civil". En este sentido, la ausencia de sistematicidad impide que la violencia sexual sea considerada como crimen de lesa humanidad, pero en nada obsta su calificación y sanción como tortura ${ }^{64}$. De hecho, la $\mathrm{CIDH}$ ha considerado en una línea jurisprudencial consolidada que existe responsabilidad del estado cuando se adoptan o mantienen normas internas que permiten la amnistía o el indulto de condenados por crímenes de tortura, en violación de la Convención Interamericana y del Derecho Internacional. De hecho, la citada sentencia Almonacid ejemplifica el diálogo entre tribunales, ya que la $\mathrm{CIDH}$ no ha dudado en recurrir a la jurisprudencia de la CEDH para confirmar su interpretación del principio de legalidad penal internacional, puesto que en el momento de comisión de los hechos no había una norma penal interna pero sí normas internacionales que tipificaban las desapariciones forzadas y las ejecuciones extrajudiciales como crímenes internacionales.

\section{B. El alcance del deber estatal de investigar y sancionar la violencia sexual}

Como corolario de este dialogo, ambos tribunales afirman sin ambages que la prohibición de la tortura, incluyendo la tortura como violencia sexual, es una norma de ius cogens o derecho imperativo que, como tal, no admite pacto en contra, por lo que los Estados tienen la obligación de proceder a su investigación y sanción, sin que este deber pueda limitarse por la aplicación de leyes de amnistía o cualquier otro tipo de normas nacionales.

${ }^{63} \mathrm{CIDH}$, Caso Almonacid Arellano y otros contra Chile, sentencia de 26 de septiembre de 2006.

${ }^{64}$ CIDH, Caso Bueno Alves contra Argentina, sentencia de 11 de mayo de 2007, párrafo 87: “(...) la Corte comparte el criterio del Estado expresado en su contestación de demanda respecto a que "si bien los actos de tortura perpetrados contra el [señor Bueno Alves] han quedado alcanzados por la protección [...] de la Convención [Americana], ello no significa que deban ser calificados per se como delitos de lesa humanidad", como lo pretende la representante de la víctima, debido a que tales actos no formaron parte de un contexto de ataque generalizado o sistemático contra una población civil". 
Por consiguiente, la cuestión del alcance del deber estatal de investigar y sancionar la violencia sexual ha de resolverse teniendo en cuenta las consecuencias que su posible tipificación como crimen internacional implican en relación al objetivo último común, que es la lucha contra la impunidad, sin que esto signifique enjuiciar la responsabilidad penal individual de sus autores. Así, cuando se trata de funcionarios estatales acusados de violación u otros abusos sexuales graves calificados de tortura, la CIDH ha entablado un dialogo a varias bandas, no solo con el TEDH, como evidencia el caso Abulsamet Yaman contra Turquía ${ }^{65}$, sino también con el TPIY, como atestigua el caso Furundzija, para alcanzar una misma conclusión: la exigencia de la máxima diligencia en la investigación y sanción de todos los agentes o funcionarios del Estado que, de una $\mathrm{u}$ otra forma, participaron permitieron, favorecieron, aceptaron $\mathrm{u}$ ocultaron la violencia sexual como tortura, ya se trate de una violación strictu sensu o de otros abusos ${ }^{66}$. Y subsiguientemente, la inadmisibilidad de cualquier decisión política o normativa (prescripción, amnistía, punto final etc.) que favorezca la impunidad.

A mayor abundamiento, la CIDH precisa que el deber del Estado de investigar los posibles actos de tortura $\mathrm{u}$ otros tratos crueles, inhumanos o degradantes (art. 5 de la Convención) se encuentra reforzado por la obligación convencional asumida en virtud de la Convención Interamericana de prevención y sanción de la tortura (arts. 1, 6 y 8) que introduce dos exigencias añadidas: la inmediatez, y el hecho de que las investigaciones no requieren comenzar a instancia de partes, ya que la autoridades nacionales procederán "de oficio y de inmediato a realizar una investigación sobre el caso y a iniciar, cuando corresponda, el respectivo proceso penal" ${ }^{\prime 67}$. Dicha investigación de oficio es imprescindible tomando en consideración el contexto sociopolítico en el que los tribunales de derechos humanos realizan su labor, donde la violencia sexual, especialmente contra las mujeres, suele tener un componente discriminatorio estructural $^{68}$.

${ }^{65}$ TEDH, Caso Abulsamet Yaman contra Turquía, sentencia de 2 de noviembre de 2004: "55. The Court further points out that where a State agent has been charged with crimes involving torture or ill-treatment, it is of the utmost importance for the purposes of an "effective remedy" that criminal proceedings and sentencing are not time-barred and that the granting of an amnesty or pardon should not be permissible. The Court also underlines the importance of the suspension from duty of the agent under investigation or on trial as well as his dismissal if he is convicted (see Conclusions and Recommendations of the United Nations Committee against Torture: Turkey, 27 May 2003, CAT/C/ $\mathrm{CR} / 30 / 5)^{\prime \prime}$.

${ }^{66}$ Sobre este particular insiste de manera muy gráfica el Amicus Curiae presentado por la Fundación para el Debido Proceso (DPLF en sus siglas inglesas) en el caso Mariana Selvas y otras contra Méjico, cuyo juicio oral tuvo lugar en noviembre de 2017, disponible en http://www.dplf.org/es/resources/ amicus-curiae-ante-corte-interamericana-sobre-caso-mariana-selvas-y-otras-vs-mexico-caso

${ }^{67} \mathrm{CIDH}$, Caso del Penal Miguel Castro Castro, ibidem, párrafo 345.

${ }^{68} \mathrm{CIDH}$, Caso Velásquez Paiz y otros contra Guatemala, sentencia de 19 de noviembre de 2015, párrafo 146.

Araucaria. Revista Iberoamericana de Filosofia, Política, Humanidades y Relaciones Internacionales, año 20, $\mathrm{n}^{\circ} 40$. Segundo semestre de 2018. Pp. 511-575. ISSN 1575-6823 e-ISSN 2340-2199 doi: 10.12795/araucaria.2018.i40.23 
Pero es que además, de la jurisprudencia de ambos tribunales se desprende que la investigación y sanción de la violencia sexual no solo es un deber sustancial, que ha de realizarse de oficio y con carácter inmediato, sino que tiene que llevarse a cabo conforme a los estándares internacionales exigidos para las más graves violaciones de los derechos humanos, lo que implica algunos "subdeberes" estatales, que a nuestro juicio serían los siguientes:

-remover todos los obstáculos de iure y de facto que impidan sancionar a todos sus responsables;

-interpretar extensivamente el concepto de responsabilidad, ya que por responsables se entiende a los funcionarios y agentes del estado (policías, militares, médicos, funcionarios de prisiones etc.), cualquiera que sea su rango o la administración a la que pertenezcan, ya sean autores materiales o intelectuales. Sobre este particular, la CIDH ha dejado claro que en la violencia sexual como tortura "se deberán investigar posibles vínculos entre los responsables directos de la violencia sexual y sus superiores jerárquicos" ${ }^{\prime 69}$. En esta misma línea, dirimir si los autores de la violencia sexual fueron varios y actuaron de manera coordinada, bajo el mando de sus superiores, abusando de sus víctimas de manera pública, masiva y reiterada, sin que los respectivos mandos o superiores evitaran tales actos primero y los denunciaran después, resulta determinante para su calificación como crimen sexual de lesa humanidad;

-desentrañar las estructuras o redes que permitieron la violencia sexual como tortura o la comisión de crímenes sexuales de guerra o de lesa humanidad, así como sus causas, beneficiarios y consecuencias;

-imponer a los autores de violencia sexual una sanción proporcional a la gravedad y daños causados, para evitar que la justicia penal sea ilusoria $\mathrm{y}$ ejercer un efecto verdaderamente disuasorio.

A modo de conclusión, en el diálogo jurisprudencial expuesto el deber de investigar constituye una obligación estatal imperativa "que deriva del derecho internacional y no puede desecharse o condicionarse por actos o disposiciones normativas internas de ninguna índole". Dicho deber comprende la investigación, con todos los subdeberes que acabamos de precisar, pero también la necesidad imperiosa de prevenir la repetición los hechos, así como la satisfacción de las expectativas de las víctimas y de la sociedad de conocer la verdad y evitar la impunidad. La obligación de investigar, en su triple dimensión

${ }^{69} \mathrm{CIDH}$, Caso Miembros de la Aldea Chichupac y comunidades vecinas del Municipio de Rabinal contra Guatemala, sentencia de 30 de noviembre de 2016, párrafo 256. 
de justicia, reparación y verdad, constituye pues un medio para alcanzar todos esos fines, cuyo incumplimiento acarrea la responsabilidad internacional del Estado $^{70}$.

Finalmente, para dilucidar plenamente cuál es el alcance real del deber de investigación y sanción de la violencia sexual a la luz de la jurisprudencia del TEDH y la CIDH es necesario incidir, siquiera brevemente, en otras dos cuestiones.

\section{Criterios para la investigación de la violencia sexual}

En el caso del TEDH y la CIDH, a diferencia de lo sucedido con los tribunales penales, y en particular con la Corte Penal Internacional, no existe ninguna norma o criterio reglado para priorizar qué tipo de violaciones de derechos humanos o crímenes internacionales merecen una atención preferencial, y si entre ellos se ha de incluir la violencia sexual. En efecto, esta selección casa mal con la esencia de los tribunales de derechos humanos, ya que primar la investigación o sanción de ciertas violaciones frente a otras implica desconocer la unidad e indivisibilidad última de los derechos humanos, amén de distorsionar la obligación que tienen todos los Estados sin excepciones de proceder a su castigo, introduciendo un sesgo discriminatorio imposible de justificar.

Cuestión diferente es si, al igual que ha sucedido con la adopción en 2014 por parte de la Fiscalía de la CPI del llamado "Documento de política sobre crímenes sexuales y por motivos de género", que sitúa la violencia sexual como una prioridad estratégica, al menos en el plano teórico, de su labor jurisdiccional $^{71}$, también estos dos tribunales han seguido esta misma tendencia. En otras palabras, si el TEDH y la $\mathrm{CIDH}$, en el marco de sus respectivas competencias, se han asegurado de que la violencia sexual sea investigada y perseguida al menos con la misma diligencia que el resto de violaciones de derechos humanos y si, a mayor abundamiento, cuando por su gravedad revista la consideración de crímenes internacionales, procuran que obtengan

${ }^{70}$ CIDH, Caso del Penal Miguel Castro Castro, op. cit, párrafo 347; Caso Masacres de Río Negro contra Guatemala, Sentencia de 4 de septiembre de 2012, párrafo 194.

71 En el punto 4 del resumen de este documento de junio de 2014 se afirma: "La Fiscalía presta especial atención a la comisión de crímenes sexuales y por motivos de género en todas las etapas de su labor: en el examen preliminar, la investigación y el enjuiciamiento (...) Además de los problemas generales que surgen en las investigaciones llevadas a cabo por la Fiscalía, ...la investigación de los crímenes sexuales y por motivos de género plantea problemas específicos. Entre ellos figuran la falta de presentación de denuncias en muchos casos, o en ninguno, por factores sociales, culturales o religiosos; la estigmatización de las víctimas; la escasez de investigaciones en el plano interno y la consiguiente falta de pruebas fácilmente disponibles; la falta de pruebas forenses o de otras pruebas documentales a causa, entre otras cosas, del paso del tiempo, y el carácter inadecuado o limitado de los servicios de apoyo a nivel nacional. La Fiscalía prestará especial atención a estos crímenes desde las primeras etapas a fin de resolver esos problemas".

Araucaria. Revista Iberoamericana de Filosofia, Política, Humanidades y Relaciones Internacionales, año $20, \mathrm{n}^{\circ} 40$. Segundo semestre de 2018. Pp. 511-575. ISSN 1575-6823 e-ISSN 2340-2199 doi: 10.12795/araucaria.2018.i40.23 
un castigo proporcional al daño infringido, sin beneficiarse de prescripción o amnistía alguna.

Por lo que se refiere al TEDH, en las páginas introductorias de este mismo trabajo hemos avanzado que, con la excepción de cierto casos a los que luego nos referiremos en los que intervienen agentes del estado, la mayoría de los supuestos de violencia sexual tienen que ver con la violencia doméstica entre particulares y la falta de diligencia de los Estados para proteger a las víctimas, cuya agresión "no sólo tiene su origen en el acto concreto del atacante, sino también en la ineficacia o inacción institucional, donde la falta de procedimientos adecuados, prácticas que no son acordes al respeto de los derechos humanos, garantías procesales, integridad psicofísica, o al respeto a la vida privada y familiar, agravan aún más la situación de violencia padecida por las mujeres"72. Es por ello que a nuestro juicio en el Consejo de Europa la importancia de la priorización de la investigación de la violencia sexual se traslada al ámbito de los derechos internos, girando en torno a lo que el propio TEDH ha calificado como "el deber de los Estados de penalizar cualquier conducta que implique un acto sexual no consentido, incluidos aquellos actos en que no existe evidencia de la resistencia física de la víctima"73.

Sin embargo, en el caso de la CIDH este compromiso sí que reviste una especial trascendencia, dado que en su ámbito geográfico han sido frecuentes toda clase de crisis y conflictos caracterizados por el recurso sistemático a la violencia sexual de todos los agentes involucrados en el mismo, tanto estatales como paraestatales, debido a la preexistencia de desigualdades estructurales (económicas, políticas, sociales, culturales y de género o patriarcados) que se exacerban durante los mismos y subsisten incluso tras su resolución. Es más, cuando los autores de la violencia sexual son agentes del Estado de hecho o de derecho la CIDH considera que el deber de diligencia en la investigación y sanción es extremo, lo que resulta incompatible con la aplicación de un principio de oportunidad o con priorizar ciertas violaciones de derechos humanos frente a otras. Por esta sería la Comisión, órgano que en el sistema interamericano está facultada, junto a los Estados, para activar su jurisdicción, quien tendría una responsabilidad añadida para evitar la impunidad crónica de la violencia sexual.

En este sentido cabe apreciar una evolución muy positiva en un doble plano. Por una parte, la Comisión Interamericana ha calificado de forma temprana e inequívoca que la violencia sexual constituye tortura, en una jurisprudencia

\footnotetext{
${ }^{72}$ Graciela Medina, "La violencia contra las mujeres en la jurisprudencia del Tribunal Europeo de Derechos Humanos", en Cuestiones de interés jurídico del Instituto de Derecho Iberoaméricano, (2015), disponible en dibe.org/cuestiones-de-interes-juridico/la-violencia-contra-las-mujeres-en-lajurisprudencia-del-tribunal-europeo-de-derechos-humanos/

${ }^{73}$ TEDH, Caso M.G.C. contra Rumania, sentencia de 16 de marzo de 2016, párrafo 59. Vid el comentario crítico de la misma realizado por Camila Troncoso, "Caso M.G.C. vs. Rumania", 2 Revista de Ciencias Penales (2016), pp. 301-312.
} 
sólida que como veremos a continuación comienza en 1996 en el caso Raquel Martín de Mejía contra Argentina y se prolonga ininterrumpidamente hasta hoy $^{74}$, en el reciente caso, Selvas Gómez y otras contra Méjico. Simultáneamente, ha redoblado sus esfuerzos en la investigación y sanción de este tipo de vulneraciones de la dignidad humana elaborando diferentes documentos internos, al modo de los "Policy Papers" de la CPI, en los que redobla su compromiso cuando dicha violencia es ejercida contra mujeres en particular riesgo, como son las niñas, las mujeres indígenas, las mujeres discapacitadas, y las mujeres afectadas por situaciones de conflicto armado. Así, en un primer informe genérico datado en 2007 sobre el "Acceso a la justicia para mujeres víctimas de la violencia en las Américas" la Comisión reconoció la falta de denuncia y el sub-registro de la violencia sexual en el sistema interamericano, para posteriormente en un segundo informe de 2011 "Acceso a la Justicia de Mujeres Víctimas de Violencia Sexual en Mesoamérica” aportar sugerencias al objeto de facilitar su persecución, en especial en los ámbitos de la salud y la educación.

Este compromiso de la Comisión Interamericana lógicamente no tendría sentido sin el de la Corte propiamente dicha y la de sus magistrados, entre los que queremos destacar el impulso que para la persecución de la violencia sexual como una prioridad de la CIDH supuso la elección en 2015 de la profesora Elisabeth Odio Benito, cuya huella ya se ha dejado notar en la jurisprudencia de los dos últimos años. A lo anterior hay que añadir el papel creciente de la sociedad civil, que a través de la figura del Amicus Curiae, ha encontrado una vía para apoyar, aunando la ética con el rigor científico, las denuncias sobre violencia sexual cometidas por un Estado parte, como atestigua por ejemplo el hecho de que en el caso del feminicidio de Ciudad Juárez la CIDH recibió 11 escritos en calidad de Amicus Curiae de personas individuales, instituciones públicas y $\mathrm{ONGS}^{75}$.

En esta misma línea, debemos también resaltar la importancia de los esfuerzos para corregir la ambigüedad inicial y lograr un mayor compromiso en la persecución de la violencia sexual por parte de las autoridades nacionales desde el mismo momento en que se denuncia. La diligencia en el inicio de las investigaciones es esencial para asegurar una instrucción con garantías de éxito,

${ }^{74}$ Con anterioridad, en los Informe sobre Haití de 1995, la Comisión calificó como crimen de lesa humanidad la tortura practicada contra las mujeres cuando son utilizados para infundir terror, y en el Informe sobre Perú de 1996 consideró la violación como un crimen de tortura, Baltasar Garzón, "Avances en la jurisprudencia internacional en violencia sexual contra mujeres en conflictos armados”, 15 The Journal Jurisprudence, 443 (2012), pp. 443-472.

${ }^{75} \mathrm{CIDH}$, caso González y otras contra Méjico ("Campo Algodonero"), sentencia de 16 de noviembre de 2009, párrafo 15. De la importancia adquirida por el "Amicus Curiae" en el sistema interamericano da fe el que en 20 años, en el periodo comprendido entre 1988 y 2008 ha estado presente en 41 sentencias contenciosas y en 16 opiniones consultivas. Sobre su importancia en los tribunales internacionales, Sara Willians/ Hannah Woolaver, "The role of the Amicus curiae before International Criminal Tribunals”, 6 International Criminal Law Review (2006), pp. 151-189.

Araucaria. Revista Iberoamericana de Filosofia, Política, Humanidades y Relaciones Internacionales, año 20, ${ }^{\circ} 40$. Segundo semestre de 2018. Pp. 511-575. ISSN 1575-6823 e-ISSN 2340-2199 doi: 10.12795/araucaria.2018.i40.23 
que a su vez evite el recurso a la $\mathrm{CIDH}$, última ratio ante la inacción o el fracaso de los tribunales nacionales. Uno de los ejemplos más significativos de compromiso del derecho interno lo constituye el obligado cambio de actitud de algunas Fiscalías nacionales, como la colombiana. Debido a la duración y virulencia del conflicto interno, en las dos últimas décadas Colombia ha sido condenada en más de 15 ocasiones por la CIDH por graves violaciones de los derechos humanos que comprenden detenciones ilegales, torturas, y/o desapariciones, pero pocas de las sentencias condenatorias se refieren expresamente a crímenes sexuales. Una de ella es la de 22 de noviembre de 2016 en el caso Yarce y otras contra Colombia $^{76}$, en las que se constató que la persecución a la que fueron sometidas las mujeres defensoras de los derechos humanos y sus familias incluyeron violaciones y otras torturas sexuales. Conscientes de la necesidad de poner coto a esta situación, la Fiscalía creó en 2016 una Unidad de Derechos Humanos y Derecho Internacional Humanitario que ha investigado ya 8 causas de violencia sexual protagonizadas por 38 paramilitares y guerrilleros ${ }^{77}$, además de aprobar ese mismo año un Protocolo sobre Investigación de Violencia Sexual ${ }^{78}$.

La dificultad estriba en que en la práctica totalidad de los crímenes sexuales en conflictos que han sido objeto de conocimiento por la $\mathrm{CIDH}$, la violencia sexual, vinculada a la discriminación y la desigualdad, es estructural. Antecede al mismo conflicto, es usada como un arma de guerra durante el mismo y se prolonga en el posconflicto, posconflicto cuya resolución se articula a través de la denominada justicia transicional, entendida como una forma especial de administrar justicia en procesos de tránsito de situaciones traumáticas de postguerra a la búsqueda de la paz o de cambio de un régimen político totalitario a otro democrático. Precisamente es sabido que la justicia transicional se caracteriza por la selección y priorización de los casos que serán objeto de investigación, enjuiciamiento y sanción, así como por la posible concesión de amnistías que ayuden a alcanzar el equilibrio entre justicia y paz ${ }^{79}$. Así pues, el

\footnotetext{
${ }^{76} \mathrm{CIDH}$, caso Yarce y otras contra Colombia, sentencia 22 noviembre 2016, párrafo 93: «Esta situación de riesgo para las defensoras de derechos de las mujeres fue también objeto de trabajo de la Representante Especial del Secretario General de las Naciones Unidas sobre defensores de derechos humanos. Después de su misión a Colombia en 2001, la Representante informó que «recibió testimonios trágicos de parte de mujeres que ha/bían] sido violadas, torturadas, amenazadas, asesinadas, desplazadas y exiliadas. [...] Las mujeres son víctimas de estas violaciones por su condición de $[\ldots]$ defensoras de los derechos humanos».

${ }^{77} \mathrm{La}$ guerra inscrita en el cuerpo, Informe Nacional de Violencia Sexual en el Conflicto Armado, Centro Nacional de Memoria Histórica, 2017, publicado el 28 de noviembre de 2017, cuantifica un total de 15.076 víctimas de violencia sexual, el 91,6\% mujeres y niñas, pero advierte también de la posible existencia de muchas más debido al sub-registro, disponible en http://www.centrodememoriahistorica. gov.co/informes/informes-2017/la-guerra-inscrita-en-el-cuerpo

${ }^{78}$ Fiscalía General de la Nación colombiana, Protocolo de Investigación de Violencia Sexual. Guía de buenas prácticas y lineamientos para la investigación penal y judicialización de delitos de violencia sexual, adoptado mediante la Resolución 01774 , de 14 de junio de 2016, disponible en https://www. fiscalia.gov.co/colombia/wp-content/uploads/Protocolo-de-investigacio \%CC\%81n-de-violenciasexual-cambios-aceptados-final.pdf

${ }^{79}$ Instrumentos del Estado de Derecho para sociedades que han salido de un conflicto. Iniciativas
} 
principal efecto colateral no deseado de la justicia transicional es una eventual brecha de impunidad, en la que solo se enjuicien determinados crímenes y autores. En el caso de la violencia sexual esa brecha es doble, puesto que la praxis demuestra que a la hora de seleccionar los crímenes, autores y víctimas no se incluye la violencia sexual, que quedaría sometida a una doble postergación: si normalmente frente al genocidio o las desapariciones forzadas, la violación o los abusos sexuales parecen perder importancia, mucho más en situaciones de justicia transicional, donde se sopesa con especial cuidado el coste-beneficio de su sanción, y se amplifican las dificultades consustanciales que plantea su investigación. Así, la praxis evidencia que en los supuestos típicos de justicia transicional que buscan poner fin a crisis, regímenes dictatoriales y/o conflictos armados, hay una escasez de procesos, ya sean en el seno de tribunales nacionales o internacionales, en los que se enjuicien crímenes sexuales y una muy insuficiente inclusión de estos crímenes en los mecanismos destinados a esclarecer la verdad y en los programas de reparaciones

De todo lo anterior se desprende la necesidad de incluir la violencia sexual y el componente de género en la justicia transicional, ya sea en los mecanismos jurisdiccionales, ya en las comisiones de la verdad, y por supuesto en los acuerdos de paz, en línea con la labor llevada a cabo por la Unidad especializada en género en la Comisión de la Verdad y la Reconciliación de Perú 2001 o Colombia). En última instancia de lo que se trata es que la justicia transicional adopte el acervo normativo sustantivo y procedimental (protección de víctimas y testigos de casos de violencia sexual, reglas de prueba etc.) desarrollado por los tribunales y órganos internacionales del sistema de justicia penal, y en especial por la CPI.

\section{Los límites y la tipología de las amnistías}

En cualquier caso, como ya hemos adelantado, la impunidad supone el límite infranqueable para todo modelo de justicia penal, también de la transicional. Tanto el Derecho Internacional general como el marco normativo regional europeo y americano imponen a los Estados de manera clara y taxativa la obligación de perseguir y sancionar los crímenes internacionales, incluyendo por supuesto los de violencia sexual, que no podrán ser objeto de ninguna medida (perdón, amnistía, prescripción, cosa juzgada etc.) que suponga «una infracción de las obligaciones que tienen los Estados de investigar las violaciones, adoptar medidas apropiadas respecto de sus autores, especialmente en la esfera de la justicia, para que las personas sospechosas de responsabilidad penal sean procesadas, juzgadas y condenadas a penas apropiadas, de garantizar

de enjuiciamiento. Oficina del Alto Comisionado de Naciones Unidas para los Derechos Humanos, Nueva York, y Ginebra, 2006.

Araucaria. Revista Iberoamericana de Filosofia, Politica, Humanidades y Relaciones Internacionales, año 20, $\mathrm{n}^{\circ} 40$. Segundo semestre de 2018. Pp. 511-575. ISSN 1575-6823 e-ISSN 2340-2199 doi: 10.12795/araucaria.2018.i40.23 
a las víctimas recursos eficaces y la reparación de los perjuicios sufridos de garantizar el derecho inalienable a conocer la verdad y de tomar todas las medidas necesarias para evitar la repetición de dichas violaciones"80.

Para finalizar quisiéramos recordar de manera sucinta, ya que esta cuestión excede con mucho de nuestro objeto de estudio ${ }^{81}$, que existen tres posibles vías de impunidad de la violencia sexual. Por una parte, la impunidad normativa o de iure, mediante la aprobación de medidas normativas de diferente rango legal que desactivan el deber de investigar y sancionar determinados delitos o a determinados criminales. Por otra parte, la impunidad fáctica o de facto, cuando a pesar de la existencia de normas que conminan a la persecución penal, el deficiente funcionamiento del sistema de justicia penal impide la investigación y sanción de las violaciones derechos humanos y crímenes perpetrados ${ }^{82}$. Y en tercer lugar, la selección o priorización de determinados crímenes y la correlativa postergación de otros comportan una tercera modalidad, que podría calificarse de amnistía encubierta ${ }^{83}$.

\subsection{La configuración de la violencia sexual como un crimen de tortura en la jurisprudencia de la CIDH y del TEDH}

Como ya ha sido puesto de relieve en los epígrafes precedentes, si bien al tipificar la violencia sexual como crimen internacional tanto la CIDH como el TEDH parten de la jurisprudencia de los órganos del sistema de justicia penal internacional, el contexto en el que ambos tribunales lleva a cabo su labor y

${ }^{80}$ Vid sobre el particular el "Conjunto de principios actualizado para la protección y la promoción de los derechos humanos mediante la lucha contra la impunidad", una adición al Informe sobre Protección de los Derechos Humanos. Impunidad, elaborado por Diane Orentlicher, experta independiente encargada de actualizar el conjunto de principios para la lucha contra la impunidad, presentado a la Comisión de Derechos Humanos de las Naciones Unidas el 8 febrero de 2005.

${ }^{81}$ Vid. por todos en la doctrina española Javier Chinchón Álvarez., "El concepto de impunidad a la luz del Derecho Internacional. Una aproximación sistémica desde el Derecho Internacional penal y el Derecho Internacional de los Derechos Humanos", 24 Revista Electrónica de Estudios Internacionales (2012); Y en la anglosajona, Naomí Roth -Arriaza, "After Amnisties are gone: Latin American National Courts and new contours of the fight against impunity", 37 Human Rights Quaterly, 341 (2015), pp. 341-382. Asimismo, la reciente contribución de Miguel Arenas Meza en este mismo volumen.

${ }^{82} \mathrm{CIDH}$, Caso de Rodríguez Vera y otros contra Colombia ("Desaparecidos del Palacio de Justicia”), sentencia de 14 de noviembre de 2014.sentencia de párrafo 488 “(...) la impunidad debe ser erradicada mediante la determinación de las responsabilidades tanto generales - del Estadocomo individuales - penales y de otra índole de sus agentes o de particulares. En cumplimiento de esta obligación, el Estado debe remover todos los obstáculos, de facto y de jure, que mantengan la impunidad".

${ }^{83}$ En esta línea se ha subrayado que "las violaciones a los derechos de las mujeres siguen aún muchas veces impunes, y los problemas vigentes. Siempre hay un problema más importante, una violación a los derechos humanos más grave o más urgente. Las mujeres quedan así, por distintos factores, postergadas en tanto "humanas", Violeta Cánoves, "Como la cigarra. Notas sobre la violencia sexual, jurisprudencia y Derechos Humanos, 2 Revista Juridica de la Universidad de Palermo (2011), p. 104.

Araucaria. Revista Iberoamericana de Filosofía, Politica, Humanidades y Relaciones Internacionales, año 20, ${ }^{\circ} 40$. Segundo semestre de 2018. Pp. 511-575. ISSN 1575-6823 e-ISSN 2340-2199 doi: 10.12795/araucaria.2018.i40.23 
su modo de pensamiento jurídico (Human Rights law thinking) explican su insistencia en dos aspectos que pueden considerarse notas distintivas de su labor jurisprudencial.

La primera particularidad en la que ambos tribunales insisten es que la determinación de la responsabilidad estatal por crímenes de violencia sexual difiere de la indagación de la responsabilidad penal individual por esos mismos hechos, respecto de la cual los tribunales de derechos humanos ni son competentes ni pretenden sustituir a los tribunales nacionales en la averiguación de la autoría y la imposición de las penas correspondientes ${ }^{84}$.

Por esta misma razón, la $\mathrm{CIDH}$ ha afirmado en las sentencias de interpretación en los casos Fernández Ortega y Rosendo Cantú, ambos contra Méjico, que declarar la responsabilidad internacional del Estado por el crimen de violación cometido por funcionarios estatales, en concreto militares, en modo alguno implica vulnerar los derechos y garantías procesales de los acusados, pues corresponde a las autoridades nacionales determinar su responsabilidad penal, ya que será en el marco de éstas investigaciones donde las autoridades nacionales deben asegurar el cumplimiento de las garantías judiciales. En realidad, en ambas sentencias interpretativas lo que se cuestionaba era el estándar probatorio aplicado por la CIDH en los crímenes de violencia sexual, cuestión sobre la que nos detendremos luego.

La segunda nota verdaderamente distintiva estriba en la configuración de la violencia sexual como un crimen de tortura, una de las aportaciones claves realizadas en paralelo por ambos tribunales, tanto en términos cronológicos como sustantivos y procedimentales.

Así, por lo que se refiere al TEDH la primera vez que calificó la violación como un acto de tortura contrario al artículo 3 del Convenio Europeo fue en la sentencia de 25 de septiembre de 1997, en el caso Aydin contra Turquía ${ }^{85}$. En concreto, la mayoría del Tribunal (14 votos contra siete) ${ }^{86}$, basándose en una

${ }^{84}$ Así lo reconoció la Sala Penal Especial de la Corte Suprema de Justicia del Perú en la sentencia del caso Fujimori de 7 de abril de 2009: “ La CIDH no declara la inocencia o la culpabilidad de una persona -en sede internacional se dilucida la responsabilidad internacional del Estado por una infracción de las normas convencionales-; y, es en sede del proceso penal donde se actuaran las pruebas necesarias para un pronunciamiento definitivo acerca de la culpabilidad o inocencia del acusado - de no ser así, resultaría innecesaria la fase probatoria del proceso penal-. La responsabilidad internacional del Estado tiene sus propios criterios de imputación, que no pueden extenderse automáticamente al campo de la responsabilidad penal -aunque éstos, también es verdad, no pueden obviarse sin más-, para lo cual se requiere una sentencia, que será condenatoria si se enerva la presunción de inocencia, lo cual no excluye por cierto tomar como un elemento importante ambos fallos internacionales, con un peso de persuasión calificado, en especial, por el ámbito común de apreciación, los hechos contextuales y patrones de comportamiento del Estado y, por cierto, de sus dirigentes en un momento determinado", accesible en http://derechoshumanos.pe/wp-content/fujimori/sentencia/P2C1_Prueba_penal.pdf

85 TEDH Caso Aydin contra Turquía, sentencia de 25 de septiembre $\overline{\text { de }} 1997$, disponible en español en https://www.cejil.org/sites/default/files/legacy_files/III.\%20Corte\%20Europea\%20de\%20 Derechos\%20Humanos_1.pdf

${ }^{86}$ El TEDH manifestó que hubiera llegado a la misma conclusión incluso si se hubieran tomado los dos motivos por separado, ratificando su opinión de que la violación implica causar sufrimiento 
decisión anterior de la Comisión Europea de Derechos Humanos, considero probado que la demandante fue detenida y llevada a una comisaría, donde le taparon los ojos, la golpearon, la desnudaron, rociándola con agua a presión, para después ser violada por un agente del estado cuya identidad no pudo ser probaba.

A nuestro juicio, dos son los elementos determinantes esgrimidos por el TEDH en la calificación de la violación como tortura. Por una parte, la doble dimensión, privada y pública, de la violencia sexual, que además del daño irreparable a la víctima la violación tenía también una finalidad ejemplarizante: ante las sospechas de colaboración de la víctima y/o su familia con el PKK (Partido de los Trabajadores del Kurdistán), el objetivo último era la obtención de información, y la difusión un mensaje genérico de advertencia a otros miembros de la comunidad. En segundo término, la gravedad y el alcance del daño infringido, ya que la distinción entre tortura y trato inhumano o degradante establecida por el artículo 3 del Convenio Europeo estriba en que el estigma especial de la tortura se aplica únicamente al trato inhumano deliberado que causa un sufrimiento muy grave y cruel, como en el caso de la violación que, a mayor abundamiento, "al ser cometida por un funcionario del Estado debe considerarse una forma de maltrato especialmente grave y aborrecible, teniendo en cuenta la facilidad con la que el infractor puede abusar de la vulnerabilidad y la debilitada capacidad de resistencia de su víctima. Además, la violación deja en la víctima profundas cicatrices psicológicas que no responden al del tiempo tan rápido como otras formas de violencia física y mental. La demandante también experimentó el dolor físico agudo de la penetración forzosa, que debió haberla hecho sentirse degradada y violada tanto física como emocionalmente. [...] A la luz de este contexto, el Tribunal está convencido de que la acumulación de actos de violencia física y mental cometidos contra la demandante y el acto especialmente cruel de la violación, a la que fue sometida, constituyen tortura en infracción al artículo 3 del Convenio" $"$.

Con posterioridad el TEDH ha precisado el contenido de la tortura como crimen de violencia sexual, matizando que cualquier forma de abusos sexuales practicados por agentes del estado pueden considerarse tortura, habida cuenta de la gravedad, inhumanidad y aberración que suponen, teniendo en cuenta la vulnerabilidad de la víctima y su fragilidad frente al agresor. Así se declaró por primera vez en el caso Aydin contra Turquía ${ }^{88}$ y se ha reiterado

en un nivel suficiente de gravedad que permita que este tipo de maltrato se ubique en la categoría de tortura. Este argumento lo compartían incluso los 7 jueces disidentes, que dudaron de la veracidad de los hechos pero no de que, de haber ocurrido, constituirían una violación extremadamente grave del artículo 3.

${ }^{87}$ TEDH Sentencia de 25 de septiembre de 1997, op. cit, párrafo 87.

88 TEDH, Caso Aydin contra Turquía, sentencia de 25 de septiembre de 1997, párrafo 83: "La violación de una detenida por parte de un funcionario del Estado debe ser considerada como un tipo especialmente grave y aborrecible de maltrato dada la facilidad con la que el infractor puede

Araucaria. Revista Iberoamericana de Filosofía, Política, Humanidades y Relaciones Internacionales, año 20, $\mathrm{n}^{\circ} 40$. Segundo semestre de 2018. Pp. 511-575. ISSN 1575-6823 e-ISSN 2340-2199 doi: 10.12795/araucaria.2018.i40.23 
posteriormente en los casos Maslova y Nalbandov contra Rusia y Yaguz Ilmaz contra Turquía. En el primero ${ }^{89}$, el TEDH declaró la responsabilidad del estado por los abusos sexuales y violación por policías mientras la víctima estaba detenida, con el agravante de que las autoridades nacionales incumplieron su deber de llevar a cabo una investigación diligente y eficaz. En el segundo caso $^{90}$, el TEDH extiende la calificación de tortura al acoso sexual y al examen dactilar ginecológico sin garantías que la denunciante, menor de edad, padeció durante su detención, para a renglón seguido reiterar que la prohibición de trato inhumano o degradante se había vulnerado no solo en razón de los citadas prácticas, sino también por la falta de una investigación adecuada y eficaz de estos hechos.

En paralelo al TEDH, la CDIDH también ha calificado los abusos sexuales como tortura en una jurisprudencia gemela, que tiene en la sentencia del caso del Penal Miguel Castro contra Perú su exponente máximo. De hecho, esta es la primera sentencia cronológicamente del diálogo jurisprudencial en la que se afirma que la inspección dactilar vaginal por parte de agentes del estado en mujeres privadas de libertad es una violación que, por sus efectos, constituye un acto de tortura ${ }^{91}$.

aprovecharse de la vulnerabilidad y la débil resistencia de su víctima. Además, la violación deja secuelas psicológicas a la víctima que no se van con el paso del tiempo tan rápido como lo harían otros tipos de violencia física y mental. La demandante también sufrió el dolor físico agudo que implica la penetración forzada, que seguramente la dejó sintiéndose degradada y violada tanto física como emocionalmente".

89 TEDH, Caso Maslova y Nalbandov contra Rusia, sentencia de 24 de enero de 2008, la denunciante fue convocada a la comisaría de su barrio e interrogada por dos policías por la presunta participación en un homicidio. Allí fue forzada a practicar sexo oral y violada, además de ser torturada mediante descargas eléctricas en los pendientes de aros que llevaba en sus orejas. Los dos policías también le pusieron una máscara de gas, que le impidió el paso del oxígeno, llegando a casi asfixiarla. Posteriormente fue violada por otros policías ebrios, que utilizaron preservativos y limpiaron la escena, con toallitas. Como consecuencia de la denuncia por violación y torturas, se encontraron rastros de células vaginales y de semen en preservativos y en otras prendas y toallitas utilizados para limpiar el lugar, pero el tribunal nacional no admitió estas pruebas por entender que no se había seguido el procedimiento especial pertinente para el caso de investigación contra oficiales de policía. Sin embargo, el TEDH consideró que la versión de la sra. Maslova estaba corroborada por pruebas irrefutables y que los actos de violencia física infringida a la denunciante (múltiples violaciones, actos crueles) constituían torturas

${ }^{90}$ TEDH Caso Yazgül Yilmaz contra Turquía, sentencia de 1 de febrero de 2011, la denunciante, que en el momento de los hechos tenía 16 años y era menor de edad, fue detenida y llevada a comisaria. Durante dicha detención denunció haber sido acosada sexualmente por los policías y sometida a un examen ginecológico para verificar su virginidad, sin ser acompañada y sin el consentimiento de su representante legal. Tras su absolución sufrió de stress postraumático y depresión. Pese a que los exámenes médicos posteriores corroboraron los abusos padecidos, los médicos penitenciarios que le practicaron los exámenes no fueron objeto de ninguna investigación. El TEDH consideró que dichos exámenes, en particular si son practicados a menores, deben realizarse con las garantías necesarias que, en el momento de los hechos, la legislación turca no preveía. Por el contrario, la práctica generalizada consistía en someter automáticamente a las mujeres detenidas a un examen ginecológico en teoría para evitar falsas acusaciones de violencia sexual contra los miembros de las fuerzas del orden, sin atender a los derechos e intereses de las detenidas.

${ }_{91}$ CIDH, Caso del Penal Miguel Castro Castro contra Perú, sentencia de 25 de noviembre de 2006, 
Por lo que se refiere a la CIDH, el volumen de casos relativos a tortura es de tal envergadura que, tal y como acertadamente se ha señalado, deviene en una de sus principales líneas jurisprudenciales ${ }^{92}$. De hecho, tanto el TEDH como la CIDH coinciden en identificar tres elementos constitutivos de la violencia sexual como un crimen de tortura prohibido en sus respectivas Convenciones y en los tratados regionales específicos ${ }^{93}$. En concreto, la CIDH sistematiza los tres elementos por primera vez en la sentencia citada del Penal Castro, pionera en la materia ${ }^{94}$, que a su vez se basa en un pronunciamiento de la Comisión Interamericana dictado una década antes, en 1996, en el caso Fernando y Raquel Mejía contra Perú ${ }^{95}$, de la siguiente forma:

a) la intencionalidad o dolo, que a diferencia de otras posibles violaciones de derechos humanos en los actos de violencia sexual se presuponen, porque nunca pueden ser fruto de una conducta imprudente, casual o fortuita;

b) la gravedad y severidad de los daños físicos y/o mentales causados, que en la violencia sexual como tortura con frecuencia sufren no solo a las víctimas, sino también sus familiares. Así, mientras que el TEH ha insistido en la crueldad, la CIDH pone el acento en que las severas consecuencias físicas y psicológicas que suelen ser más difícilmente superables por el paso del tiempo que en otras experiencias traumáticas, aun cuando no existan evidencias de lesiones o enfermedades físicas ${ }^{96}$.

c) el propósito o fin perseguido que el/los autores, funcionarios públicos o personas privadas actuando a instigación de estos, persiguen con la violencia sexual. Tal y como ha quedado de manifiesto, la doble condición

párrafo 312 .

${ }_{92}$ Eduardo Ferrer McGregor, op. cit. Hasta 2014 la Corte IDH conoció de 89 casos sobre tortura y otros tratos o penas crueles inhumanos o degradantes, lo que representaba un $51,74 \%$ del total de casos.

${ }_{93}$ Vid. en el marco de la CIDH el artículo 5.2 de la Convención Americana, y el artículo 2 de la Convención Interamericana para prevenir y sancionar la tortura de 12 de septiembre de 1985 . Y por lo que concierne al TEDH, el artículo 3 del CEDH y el Convenio Europeo para la prevención de la tortura y de las penas o tratos inhumanos o degradantes de 26 de noviembre de 1987).

${ }_{94}$ Mónica Feria Tinta., "Primer caso internacional sobre violencia de género en la jurisprudencia de la Corte Interamericana de Derechos Humanos: el caso del penal Miguel Castro Castro, un hito histórico para Latinoamérica", 3 Revista CEJIL (2007), pp. 30-45.

${ }_{95}$ Comisión IDH, Caso Raquel Martín de Mejías contra Perú, sentencia de 1 de marzo de 1996. La Sra. Martín de Mejía, después de presenciar como su marido era sacado a la fuerza de su domicilio en junio de 1989, fue violada dos veces por un militar del ejército peruano. Inicialmente no presentó denuncia ante los tribunales internos por temer exponerse así "al ostracismo público y a un mayor daño o peligro físico" y tras recibir llamadas amenazándola de muerte por querer investigar el asesinato de su esposo, en agosto de 1989 abandonó su país en dirección a Estados Unidos, y de allí a Suecia, donde obtuvo asilo político.

${ }_{96} \mathrm{TEDH}$, Caso Aydin, op . cit., párrafo 86 y CIDH, Caso Masacres de Río Negro contra Guatemala, sentencia de 4 de septiembre de 2012, párrafo 132.

Araucaria. Revista Iberoamericana de Filosofía, Política, Humanidades y Relaciones Internacionales, año 20, $\mathrm{n}^{\circ} 40$. Segundo semestre de 2018. Pp. 511-575. ISSN 1575-6823 e-ISSN 2340-2199 doi: 10.12795/araucaria.2018.i40.23 
A partir de estos tres elementos, la CIDH, en línea con el TEDH (casos Aydin contra Turquía y Yazgül Yilmaz contra Turquía) configura una jurisprudencia reiterada y constante, de la que dan fe los casos Fernández Ortega y otros contra Méjico $^{97}$ y Rosendo Cantú y otra contra Méjico ${ }^{98}$, subrayando que las violaciones perpetradas por agentes del Estado son especialmente reprobables y graves por el abuso de poder y la vulnerabilidad de las víctimas, así como por la gravedad de los daños físicos y psicológicos, que ni siquiera el paso del tiempo permite superar.

Yendo un paso más allá, la CIDH matiza que la calificación de la violación o de los abusos sexuales como tortura es independiente de la frecuencia o del lugar donde se cometa, ya que "aun cuando consista en un solo hecho u ocurra fuera de instalaciones estatales. Esto es así ya que los elementos objetivos y subjetivos que califican un hecho como tortura no se refieren ni a la acumulación de hechos ni al lugar donde el acto se realiza, sino a la intencionalidad, a la severidad del sufrimiento y a la finalidad del acto, requisitos que en el presente caso se encuentran cumplidos"99. Así, en los primeros casos las víctimas de la violación eran mujeres indígenas, un colectivo especialmente vulnerable en un contexto de "violencia institucional castrense", pero la diferencia estriba en que mientras que en el caso Rosendo Cantú las violaciones son cometidas por dos militares fuera de las instalaciones estatales, en un arroyo cercano al domicilio de las víctimas donde éstas habían acudido a lavar la ropa, en el caso en curso Mariana Selvas y otras, también contra Méjico, las once mujeres víctimas padecieron diferentes abusos sexuales constitutivos de tortura perpetrados primero por policías en el momento de su detención, y posteriormente por los agentes estatales encargados de su ingreso en diferentes centros oficiales.

Junto a la vulnerabilidad de las víctimas de torturas sexuales, la CIDH señala la prepotencia e intencionalidad de los victimarios, agentes del estado, quienes se prevalieron de su poder, causándoles un dolor y humillación agravado, debido a su vulnerabilidad múltiple. En unos casos, dicha vulnerabilidad provenía del desconocimiento del idioma utilizado por los agresores y las demás autoridades intervinientes, y en otros del repudio de su comunidad tras los hechos, respecto de los cuales las autoridades nacionales no llevaron a cabo una investigación imparcial, sería y efectiva. La CIDH ha insistido certeramente, en línea con la jurisprudencia de los tribunales penales internacionales y de algunos de los tribunales nacionales de los Estados parte, que a través de la violencia sexual no solo se daña irreparablemente a la

${ }^{97}$ CIDH, Caso del Penal Miguel Castro contra Perú, fondo, reparaciones y costas, sentencia de 25 de noviembre de 2006.

${ }_{98} \mathrm{CIDH}$, Caso Fernández Ortega y otros contra Méjico, excepción preliminar, fondo, reparaciones y costas, sentencia de 30 de agosto de 2010 .

${ }^{99} \mathrm{CIDH}$, sentencia de 31 de agosto de 2010, op. cit., párrafo 118.

Araucaria. Revista Iberoamericana de Filosofia, Política, Humanidades y Relaciones Internacionales, año 20, $\mathrm{n}^{\circ} 40$ Segundo semestre de 2018. Pp. 511-575. ISSN 1575-6823 e-ISSN 2340-2199 doi: 10.12795/araucaria.2018.i40.23 
víctima, sino también se humilla y se somete a la familia, a la comunidad e incluso al propio Estado como tal ${ }^{100}$.

\subsection{La violación como crimen sexual por antonomasia del diálogo jurisdiccional inter-regional}

Junto a la categorización de la violencia sexual como tortura, otra de las notas distintivas del dialogo entre la CIDH y el TEDH reside en el tratamiento preferencial que ambos tribunales otorgan a la violación que, al igual que sucede en la jurisprudencia de los tribunales penales, constituye el crimen sexual por antonomasia en términos cualitativos y cuantitativos.

\section{A. Concepto de violación. Elementos definitorios}

Así, en primer lugar, en lo que se refiere al concepto de violación, los dos tribunales se caracterizan por sostener un concepto amplio, en el que tiene cabida no solo la penetración por vía vaginal o anal, por insignificante que sea, conductas tradicionalmente constitutivas del tipo penal, sino cualquier otro acto llevado a cabo sin el consentimiento de la víctima que implique "la utilización de otras partes del cuerpo del agresor u objetos, así como la penetración bucal" ${ }^{101}$. Esta flexibilidad interpretativa se sustenta en la comprensión de la violencia sexual como una categoría genérica que "puede incluir actos que no involucren penetración o contacto físico alguno"102, lo que abarcaría las inspecciones vaginales dactilares ya comentadas a propósito de los casos de Aydin contra Turquía del TEDH y del Penal Miguel Castro de la CIDH ${ }^{103}$.

No obstante, la laxitud en la conceptualización está constreñida por la necesidad de diferenciar la violación de otros abusos sexuales, cometidos también sin consentimiento y que pueden afectar a los genitales de la víctima pero que, al no implicar penetración, no son considerados violación. Así ocurre

100 Por decirlo en los términos en los que se expresa la Corte Constitucional colombiana, en el Auto 092 de 2008, la violencia sexual ha sido "una práctica habitual, extendida, sistemática e invisible en el contexto del conflicto armado, cometida por todos los actores para causar terror y controlar a las comunidades ya a la propia sociedad".

${ }^{101}$ CIDH, caso Penal caso del Penal Miguel Castro, op. cit, párrafo 310.

${ }_{102} \mathrm{CIDH}$, caso Fernández Ortega y otros contra Méjico, sentencia de 30 de agosto de 2010, párrafo 119. En la misma línea caso Rosendo Cantú, op. cit, párrafo 109.

${ }_{103}$ No obstante, el TEDH modificó de forma muy criticable su posición inicial en el caso Yavuz contra Turquía, sentencia de 10 enero de 2006, al considerar que Turquía no había vulnerado el CEDHLF al someter a una mujer detenida a exámenes ginecológicos y un examen rectal el primer y el último día de su detención, como medida preventiva para evitar acusaciones de abuso sexual por parte de la policía. Los jueces Hedigan y Björgvinsson emitieron una opinión parcialmente disidente en la que consideraron que este tipo de exámenes supuso un trato inhumano al generar en la victima sentimientos de miedo, angustia e inferioridad, susceptibles de humillarla y degradarla. Vid. José María Larralde., "El Tribunal Europeo de Derechos Humanos y la protección de los derechos de las mujeres", 7 Criterio Jurídico Garantista (2012), pp.58-79. 
con lo que la CIDH llama tocamientos o "manoseos sexuales"104, amén de con la desnudez forzada, abusos sexuales que en ocasiones revisten especial gravedad porque además de una vejación de la dignidad personal supone una forma de humillación y sometimiento individual y colectivo. La propia CIDH lo reconoce en el caso Espinoza González contra Perú, en el que las mujeres fueron obligadas a permanecer desnudas durante el tiempo que duró su detención mientras que eran constantemente observadas por hombres armados ${ }^{105}$.

El segundo elemento definitorio de la violación radica en la ausencia de consentimiento de la víctima, que no en la fuerza. Es importante resaltar que la jurisprudencia internacional admite que la falta de consentimiento no exige que la víctima oponga resistencia física, hasta el extremo de que el no consentimiento se presume en situaciones de coerción en las que el victimario ostenta una posición de superioridad sobre la víctima, por ejemplo derivada de su condición de funcionario público, y abusa de su poder y de la vulnerabilidad de ésta ${ }^{106}$.

En concreto, la violación de mujeres por agentes del estado como una práctica sistemática constitutiva de un crimen de tortura es el hilo conductor de una profusa jurisprudencia sobre "masacres", que se inicia con el caso Masacre Plan de Sánchez contra Guatemala de 2004, continúa en Guatemala en el caso de la Masacre de las Dos Erres de 2009, se prologan en el caso Masacres de El Mozote y lugares aledaños contra El Salvador de 2012, y persiste en la actualidad, como evidencia el caso Favela Nova de Brasilia contra Brasil de 2017. En ella, merced a una interpretación conjunta de la Convención Interamericana y de la Convención de Belém do Pará, se insiste en que la elección de las mujeres como víctimas de violación y otros crímenes tales como esterilizaciones o abortos forzados, por ejemplo contra las mujeres mayas, pretende destruir la dignidad de las víctimas dañando gravemente su integridad física y mental, pero tiene además un efecto simbólico contra la comunidad o la parte contraria. Por todo ello, constituye una ofensa a la dignidad humana y una manifestación de las relaciones de poder y desigualdad que, como señala en preámbulo de la Convención de Belem do Pará, "trasciende todos los sectores de la sociedad independientemente de su clase, raza o grupo étnico, nivel de ingresos, cultura, nivel educacional, edad o religión y afecta negativamente sus propias bases".

${ }^{104}$ CIDH, Caso J.V, contra Perú, sentencia de 27 de noviembre de 2013, párrafos 321 y 360.

105 CIDH, Caso Espinoza González contra Perú, sentencia de 20 de noviembre de 2014, párrafo 194: "En el presente caso la Corte ha establecido que (....) Gladys Espinoza fue objeto de desnudez forzosa y manoseos, le jalaron los senos y los vellos púbico y uno de sus agresores intentó meterle el pene en su boca (...). Igualmente la Corte estableció que, durante el periodo mencionado, la señora Espinoza sufrió penetración vaginal y anal con manos, y en este último caso, también con un objeto (...) los cuales constituyeron actos de violación sexual".

106 Sobre este particular existe una vasta bibliografía, vid. por todos Catharine A. Mackinnon "Rape redefined", 10 Harvard Law and Politics Review (2016), pp. 431-477.

Araucaria. Revista Iberoamericana de Filosofia, Política, Humanidades y Relaciones Internacionales, año 20, $\mathrm{n}^{\circ} 40$. Segundo semestre de 2018. Pp. 511-575. ISSN 1575-6823 e-ISSN 2340-2199 doi: 10.12795/araucaria.2018.i40.23 
Debido al constante recurso a la violencia sexual que transforma el cuerpo de la mujer en escenario del conflicto político o armado, la CIDH ha puesto especial énfasis en que la violación obedece a un sistema que justifica la dominación masculina, sistema originado en la familia pero que se proyecta en todo el orden social ${ }^{107}$. Tal y como hemos reiterado, con la violación no solo se vulneran bienes jurídicos privados sino que se ejecuta "una forma paradigmática de violencia contra las mujeres cuyas consecuencias, incluso, trascienden a la persona de la víctima"108.

Ciertamente en todos nuestros trabajos sobre la materia insistimos en que el concepto de violación es neutral en cuanto al género, ya que tanto los victimarios como las víctimas pueden ser hombres y/o mujeres, pero no es menos cierto que los dos tribunales han dedicado una atención preferencial a la situación de discriminación estructural que padecen las niñas y mujeres basada en consideraciones de género ${ }^{109}$, así como al deber de diligencia y la subsiguiente responsabilidad de los Estados cuando dicha situación desemboca en la comisión de crímenes sexuales.

Por eso, en tercer lugar, al definir la violación los dos tribunales insisten en la obligación de los Estados de prevenir, sancionar y erradicar la violencia sexual contra las mujeres, y en particular aquellas especialmente vulnerables, caso de las menores, de las indígenas o de las desplazadas.

Quizás el caso más paradigmático en este sentido es González y otras (“Campo Algodonero") contra Méjico de 2009. En él la CIDH afirma que si bien en el feminicidio ${ }^{110}$ que tuvo lugar en Ciudad Juárez los motivos y perpetradores de los homicidios fueron múltiples, todos ellos ocurrieron en un contexto de discriminación contra la mujer conocido y tolerado por el Estado. De hecho, las autoridades mejicanas, lejos de tomar medidas que redujeran el riesgo que corrían las mujeres, una vez que los abusos sexuales y homicidios tienen lugar mantuvieron su inacción e indiferencia. La falta de diligencia en la investigación y sanción, con la consiguiente impunidad de la violencia sexual, acarrean la responsabilidad internacional estatal por: "la falta de medidas de protección a las víctimas, dos de las cuales eran menores de edad; la falta de prevención de estos crímenes, pese al pleno conocimiento de la existencia de un patrón de violencia de género que había dejado centenares de mujeres y niñas

${ }^{107} \mathrm{CIDH}$. Acceso a la justicia para mujeres víctimas de violencia sexual en Mesoamérica. OEA/ Ser.L/V/II. Doc. 63, 9 de diciembre de 2011, Resumen Ejecutivo, párrafo 45.

${ }_{108}$ CIDH, Caso Rosendo Cantú y otra contra México, op. cit, párrafo 109.

109 Tatsiana Ushakova, "La protección contra la violencia de género en el sistema interamericano de Derechos Humanos", 22 Dereito (2013), pp.53-86.

${ }^{110}$ El feminicidio o femicidio es una suerte de categoría en la que tienen cabida diferentes formas de violencia: la íntima o familiar, la no intima, la social o por conexión y el feminicidio sexual al que aludimos en este trabajo, fundamentalmente "asesinatos de mujeres precedidos de tortura y abusos sexuales”, en palabras de Celeste Saccomano, "El feminicidio en América Latina:¿vacío legal o déficit del Estado de derecho?”, 117 Revista Cidob d'Afers Internacionals (2017), p. 55 
asesinadas; la falta de respuesta de las autoridades frente a la desaparición [...]; la falta de debida diligencia en la investigación de los asesinatos [...], así como la denegación de justicia y la falta de reparación adecuada"111.

Este mismo razonamiento se repitió en 2014 en el caso Veliz Franco y otros contra Guatemala, en el que la investigación de la desaparición y posterior asesinato de mujeres jóvenes, algunas menores de edad, se caracterizó por los prejuicios y estereotipos de género sobre la vida sexual previa de las víctimas, que influyeron en la actuación lenta y negligente de las autoridades estatales ${ }^{112}$.

\section{B. La violación intrafamiliar y la violación padecida por hombres}

Por último, pero no menos importante, en relación a la definición de la violación, cabe destacar dos aportaciones propias del diálogo jurisdiccional entre ambos tribunales, que se traducen en contribuciones originales sobre lo que hemos bautizado como la violación doméstica o familiar y la violación y otros abusos sexuales padecidos por hombres.

Así, respecto a la tipificación de la violencia sexual doméstica, el TEDH desarrolla una línea pionera, en la que enfatiza la obligación de los Estados de perseguir de manera efectiva la violación o cualquier otro abuso sexual no consentido, incluso si el autor es un simple particular (familiar, vecino etc.) y la víctima no hubiera presentado resistencia física. Así, en el caso M.C. contra Bulgaria de 2003, se da un primer paso al declarar que los Estados tienen la obligación de disuadir de la comisión de actos de violencia sexual mediante disposiciones eficaces de derecho interno que la penalicen eficazmente, y que se apliquen en la práctica mediante investigaciones y procesos judiciales eficaces. Y máxime si, como en este supuesto, la víctima es un menor de edad u otra persona vulnerable que solo lograban obtener el amparo judicial demostrando su resistencia activa. De manera tajante el TEDH dice "estar convencido de que cualquier enfoque limitado que sea utilizado para condenar los delitos sexuales, como requerir pruebas de resistencia física en todos los casos, puede llevar a que ciertos tipos de violación no sean penados", por lo que atribuye el fracaso de las autoridades para investigar "al énfasis excesivo que pusieron sobre las pruebas directas de la violación. El enfoque que tomaron en el caso en cuestión fue restrictivo, y prácticamente tomaron el factor "resistencia" como un elemento definitorio del delito" ${ }^{113}$.

\footnotetext{
${ }^{111}$ No obstante la CDIH también matiza que la atribución a un Estado de la violación de una mujer cometida por un particular contra otro no es automática, sino que "debe atenderse a las circunstancias particulares del caso y a la concreción de dichas obligaciones de garantía", Caso González y otras ("Campo Algodonero") contra Méjico, Sentencia de 16 de noviembre de 2009, párrafo 280.

${ }_{112}$ CIDH, Caso Veliz Franco y otras contra Guatemala, sentencia de 19 de mayo de 2014, párrafo 208. Sobre los prejuicios contra las mujeres y la violencia sexual Emanuela Cardoso Onofre De Alencar, op. cit, en especial p. 40 y ss. .

${ }_{113}$ TEDH, Caso M.C contra Bulgaria, sentencia de 4 de diciembre de 2003, párrafos 166 y 182.
} 
Con posterioridad, en el caso M.G.C. contra Rumania de 2016 el TEDH, ha ampliado la obligación de los estados de promulgar leyes penales que efectivamente sancionen la violación de menores vulnerables por particulares de su entorno sin aparente uso de la fuerza, así como de aplicar dichas disposiciones a través de una investigación y enjuiciamiento precisando que ha de hacerse "de conformidad con los estándares internacionales", para cuya determinación toma expresamente como modelo la jurisprudencia de los tribunales internacionales pero incomprensiblemente ignora a la $\mathrm{CIDH}^{114}$. La insistencia del TEDH en precisar el alcance del deber estatal tiene como corolario su pronunciamiento el caso Opus contra Turquía de 2009, en el que se afirma que toda forma de violencia contra las mujeres ha dejado de ser un asunto privado, de manera que los estados serán responsables si, como sucedió en este asunto, se constata una omisión de la diligencia debida frente a denuncias reiteradas de violación en el seno de la familia, sumado a la posterior negligencia y discriminación en la administración de justicia.

Estos avances en la lucha contra la impunidad de la violación han permitido, pese a ciertas dificultades ${ }^{115}$, extender los deberes estatales de investigación y sanción a otros delitos sexuales, por ejemplo la prostitución forzada y la trata de personas, como atestigua el caso Rantseva contra Chipre y Rusia de 2010 ${ }^{116}$. En el mismo se condenó a las autoridades chipriotas porque inexplicablemente la policía entregó a la joven, que había intentado huir, a sus tratantes, y posteriormente tampoco investigó adecuadamente su asesinato tras ser hallada muerta en circunstancias que nunca se esclarecieron. Por su parte, Rusia fue considerada responsable por no investigar la posibilidad de que la mujer hubiera caído en manos de proxenetas individuales o de redes de trata que operaban en este país con destino en Chipre, donde eran usadas en la industria del sexo.

Por sus características, el grueso de la atención de la CIDH se ha centrado en las violaciones perpetradas por agentes del Estado y no por particulares, pero también ha abordado el problema de la violación intrafamiliar en el caso V.R.P., V.P.C y otros contra Nicaragua de 2018. En este reciente pronunciamiento, siguiendo la estela del TEDH, se atribuye responsabilidad a las autoridades estatales por las irregularidades en el transcurso de la investigación y el proceso penal por las violaciones y otros abusos sexuales padecidos por una niña y perpetrados presuntamente por su padre, quien fue absuelto en un juicio con jurado. La CIDH consideró que la menor sufrió una doble violencia, la sexual

114 TEDH, M.G.C. contra Rumania, op. cit, sentencia de 16 de marzo de 2016, párrafo 56.

115 Fundamentalmente se ha criticado que "la confusión en el caso Rantseva entre la trata sexual, la esclavitud sexual y el trabajo forzoso, aun cuando probablemente ayudara a quienes eran litigantes, puede interpretarse como el resultado de la falta de deseo de entrar en el debate sobre la realidad de la prostitución - ¿es explotación sexual o trabajo sexual?- y por lo tanto de la trata para estos fines". Catharine A. MacKinnon "Rantsev. V. Chipre \& Rusia, App. n 25965/04 (Eur. Ct. H.R. Ene 7, 2010", en 7 Anuario de Derechos Humanos (2011), p. 110, disponible en https://anuariocdh.uchile.cl/.

${ }^{116}$ TEDH, caso Rantseva contra Chipre y Rusia, sentencia de 7 de enero de 2010. 
por parte de un particular, y la violencia institucional por cuenta del Estado, que se convirtió en un segundo agresor al cometer diversos actos revictimizantes ${ }^{117}$.

La segunda aportación significativa de la jurisprudencia de ambos tribunales consiste en el reconocimiento de que los hombres y niños también son víctimas de violación, así como de cualquier otra forma de abuso sexual cuyo tipo penal lo permita, en consonancia con el esfuerzo de visibilización de esta problemática realizado por los tribunales del sistema de justicia penal internacional. Así, en su abordaje de la violencia sexual intrafamiliar, el TEDH ha aclarado que los niños y los hombres pueden ser también víctimas de la misma, razón por la cual en el caso de E. y otros contra el Reino Unido consideró que las autoridades estatales habían sido negligentes en la detección de los abusos reiterados de todo tipo que la pareja de la madre infringió a los cuatro demandantes (tres hermanas y un hermano menores de edad), sin distinciones por razón del sexo de las víctimas. Sin embargo, como se ha señalado certeramente, el asunto presentaba un indiscutible componente de género que el TEDH ignoró, ya que mientras que las tres chicas padecieron violaciones y otros abusos sexuales, el menor varón sufrió violencia física y trato inhumano, pero no violencia sexual ${ }^{118}$.

Por lo que se refiere a la CIDH, el tratamiento de la violencia sexual masculina ha experimentado una lenta y compleja evolución, desde una posición inicial de absoluta ignorancia del problema hasta un reciente reconocimiento expreso $^{119}$. El punto de inflexión de este cambio por etapas viene marcado por el caso Rodríguez Vera y otros contra Colombia de $2014^{120}$. Hasta esa fecha en una primera fase la CIDH no contempló en absoluto la posibilidad de que los niños y hombres puedan sufrir violencia sexual. Posteriormente se limitó a calificar las lesiones que estos sufrieron en sus órganos genitales como actos de tortura, pero omitiendo pronunciarse sobre si los mismos respondían al patrón de violencia sexual. De hecho, incluso realizó una distinción negativa respecto de la desnudez forzada, que en el caso del Penal Miguel Castro fue reconocida como violencia sexual solo respecto de las mujeres, pero no en los hombres. Y ello pese a que a nuestro juicio obligar a personas detenidas a exponer permanentemente sus partes íntimas a terceros constituye un acto de violencia sexual con independencia del sexo de las víctimas, si bien como señaló el juez Cançado Trindade en su voto razonado al subrayar "la necesidad e importancia

117 CIDH, Caso V.R.P., V.P.C y otros contra Nicaragua, sentencia de 8 de marzo de 2018, en especial párrafos 297 y 298.

118 TEDH, caso de E. y otros contra el Reino Unido, sentencia de 26 de noviembre de 2011. En relación a la manifiestamente mejorable posición del TEDH, Rosa A. Alija Fernández, "La violencia doméstica contra las mujeres y el desarrollo de estándares normativos de derechos humanos en el marco del Consejo de Europa”, 24 Revista General de Derecho Europeo (2011), p. 11.

119 Patricia Tarre Moser/Salvador Leyva Morelos-Zaragoza, op. cit., en especial p. 80 y ss.

${ }^{120} \mathrm{CIDH}$, Caso de Rodríguez Vera y otros contra Colombia ("Desaparecidos del Palacio de Justicia”), sentencia de 14 de noviembre de 2014. 
del análisis de género"121, el impacto puede ser mayor en las mujeres sobre todo si, como sucedió en este supuesto, los victimarios eran hombres armados.

Sin embargo, a partir de la citada sentencia de 2014 por primera vez se admite que ciertos actos que involucran la zona genital de los hombres implican una invasión de su intimidad y, por su naturaleza son un acto de violencia sexual constitutivo de torturas. A mayor abundamiento, de manera idéntica a lo afirmado cuando las víctimas son mujeres, al ser realizado por un agente del Estado contra una persona privada de libertad bajo custodia estatal "es un acto grave y reprobable, tomando en cuenta la vulnerabilidad de la víctima y el abuso de poder que despliega el agente. Dicho acto resulta denigrante y humillante física y emocionalmente, así como puede causar consecuencias psicológicas severas para la víctima".

\section{Los obstáculos técnico procesales en la investigación y sanción de la violación}

Finalmente, el análisis hasta aquí realizado de la construcción por parte de ambos tribunales de un marco jurídico regulador de la violencia sexual en general y de la violación en particular no puede considerase completo sin abordar, aunque sea de manera breve, el desarrollo de su dimensión procedimental. Y ello porque a nuestro juicio los problemas prácticos que plantea la investigación y sanción de la violencia sexual son tan importantes como las cuestiones de naturaleza sustantiva, de ahí que en sus respectivas jurisprudencias hayan empezado a ocuparse de lo que hemos bautizado como la cadena de obstáculos técnicos procesales ${ }^{122}$. En este sentido, tanto el TEDH como la CIDH parecen haber entablado no tanto un diálogo mutuo sino con los tribunales penales internacionales que, por su trayectoria y experiencia, les han servido como punto de referencia ineludible primero en la identificación y posteriormente en la resolución de dichos obstáculos, entre los que destacamos tres: la necesidad de especialización; la especificidad de la prueba y la protección de las víctimas y los testigos.

En relación a la necesidad de especialización, a medida en que ambos tribunales se han ido ocupando de un mayor número de casos en los que las vulneraciones de los derechos humanos incluían actos de naturaleza sexual, han tomado consciencia de la necesidad de que su investigación se realice por personal especializado de las diferentes administraciones (justicia, salud, fuerzas y cuerpos de seguridad del estado, servicios sociales) y de conformidad con los protocolos que este tipo de violencia requiere. Solo así las autoridades nacionales implicadas cumplirían con el deber estatal de diligencia debida,

${ }^{121}$ Voto razonado del juez A. A. Cançado Trindade a la sentencia de 25 de noviembre de 2006, párrafos 58 a 69.

${ }^{122}$ Isabel Lirola/Magdalena Martín, Crímenes internacionales, op. cit, pp. 135-151. 
eludiendo una eventual responsabilidad internacional del estado. Se trata de una medida básica pero de difícil implementación, puesto que con frecuencia los agentes del Estado participantes en el proceso en calidad de jueces, médicos etc., en lugar de contribuir al esclarecimiento de los hechos, han colaborado, intencionadamente o por falta de pericia, en la negación y el ocultamiento de la violencia sexual sufrida por las víctimas.

Por ello se explica que en el caso Rosendo Cantú se insistiera en que la reparación a la víctima de violación exigía la aprobación inmediata por el estado de medidas normativas específicas, para las que se propuso como ejemplo la Ley Orgánica 1/2004 de Protección Integral contra la violencia de Género a fin de asegurar que a las víctimas se les dispensa el tratamiento oportuno en todos los niveles (médico, psicológico, legal) que merecen ${ }^{123}$.

Por lo que se refiere a la valoración de la prueba, el vacío normativo inicial característico de la Convención de Roma y del Pacto de San José se ha cubierto por la vía de los Reglamentos de funcionamiento interno de ambos tribunales. Teniendo en cuenta su modo de pensamiento jurídico, en el que está muy presente la gravedad de las violaciones a los derechos humanos y la protección de las víctimas (Human rights law thinking), se consagran dos principios. Por una parte, la libre valoración de la prueba con justificación por el órgano jurisdiccional de la misma, y por la otra, una mayor flexibilidad procesal frente a la rigidez propia de los procesos penales internos, puesto que como hemos subrayado en varias ocasiones, ninguno de los dos tribunales dirimen la responsabilidad penal individual ni la inocencia o culpabilidad, sino la responsabilidad internacional del Estado ${ }^{124}$.

Sobre esta base, la CIDH ha reiterado la importancia de la prueba testimonial en la violación, incluyendo obviamente las declaraciones de las propias víctimas, que con frecuencia son determinantes por tratarse de los llamados "casos de testigos únicos" en los que no resulta posible recabar otros testimonios directos ${ }^{125}$. Junto a las particularidad de la prueba testimonial, también se ha insistido en las peculiaridades de la prueba documental en conexión con el deber de realizar una investigación diligente, lo que incluye que tras la agresión sexual se han de realizar exámenes médicos inmediatos conforme a

${ }^{123}$ Informe que como "Amicus Curiae" presentan el Consejo General de la Abogacía Española y la Fundación del Consejo General de la Abogacía Española ante la Honorable Corte Interamericana de Derechos Humanos en el caso Rosendo Cantú contra Méjico. Defiende la Ley española como ejemplo por tratarse de un instrumento normativo transversal pero que pone el foco en la capacitación de los diversos profesionales en materia de género y de violencia sexual, así como en la elaboración de protocolos propios.

${ }^{124}$ Javier Mariezcurrena,/Pablo Rovatti "Valoración de la prueba de la violencia sexual en la jurisprudencia de la Corte Interamericana de Derechos Humanos,", en La Constitución y sus garantías. A 100 años de la Constitución de Querétaro de 1917, Eduardo, Ferrer MacGregor, Rogelio Flores Pantoja (coords), 2017, pp. 541-574.

${ }^{125}$ Carolina Rodríguez Bejarano, "El estándar de la prueba indiciaria en los casos de violencia sexual ante la Corte Interamericana de Derechos Humanos", Memorando de Derecho, 2011, pp. 23-36. 
la especialización y los estándares internacionales referidos, complementados a posteriori por los certificados periciales que evalúen el daño sufrido por la víctima, así como con los informes de las fuerzas y cuerpos de seguridad, sobre todo si la violación o abusos sexuales se cometen en instalaciones bajo su control. De hecho, cuando se acredita la existencia de un patrón o práctica generalizada de violación por parte de agentes del Estado contra mujeres, como sucedió en el caso Espinoza Gonzáles, la CIDH invierte la carga de la prueba, dando por válido el testimonio de la víctima y por probados los hechos, salvo que las autoridades estatales consigan desvirtuar esa presunción ${ }^{126}$. En los restantes supuestos, tal y como se desprende de los casos Fernández Ortega y Rosendo Cantú, la carga de la prueba no se modificó y tampoco se evaluaron aisladamente las declaraciones de las presuntas víctimas de la violación, sino que su testimonio formó parte del conjunto del acervo probatorio.

Para completar este breve repaso, por lo que concierne a la protección de los testigos y las propias víctimas de la violencia sexual, ambos tribunales coinciden en que los testigos, cuyo testimonio normalmente corresponde a un momento anterior o justo posterior a la violación o los abusos, no podrán ser recusados o inhabilitados para declarar por razón de su nacionalidad, ideología, parentesco con la víctima o cualesquiera otro motivo personal, correspondiendo a las partes demostrar la veracidad o no de su testimonio en el transcurso del proceso contradictorio. De la misma manera, a la hora de determinar la credibilidad del testimonio de las víctimas, en el caso del feminicidio de Ciudad Juárez se alertó sobre el peligro de los estereotipos de género y la improcedencia de tomar en consideración la vida social o sexual anterior de la víctima ${ }^{127}$. Con vistas a garantizar su protección durante el juicio, hay que ponderar la vulnerabilidad de las víctimas, el esfuerzo que en la mayoría de ocasiones han tenido que hacer para denunciar a los autores, en particular si se trata de agentes del estado de rango elevado, así como las consecuencias que para ellas comporta el proceso y la sentencia, incluyendo el elevado riesgo de revictimización y de estigmatización.

\subsection{Otros crímenes sexuales en el diálogo interregional}

La violación no agota la lista de crímenes sexuales de los que han tenido que conocer la CIDH y el TEDH o puedan llegar a hacerlo en el futuro, aunque se trate, sin duda, del crimen de esta naturaleza más recurrente en sus respectivas jurisprudencias. Por tanto, una visión completa del alcance y la intensidad del

\footnotetext{
126 Julieta Di Corleto, "La valoración de la prueba en casos de violencia de género", en Garantías constitucionales en el proceso penal, Plazas, Florencia y Hazan Luciano, 2015, pp. 1-16.

127 Julieta Di Corleto/ Maria L. Piqué., "Pautas para la recolección y valoración de la prueba con perspectiva de género", en Género y Derecho Penal. Homenaje al Prof. Wolfgang Schöne, José Hurtado Pozo (ed.), 2017, en especial pp. 415-423.
} 
diálogo interregional en materia de violencia sexual requiere tener en cuenta la lista completa de crímenes de violencia sexual recogidos en los arts. 7, 1, g) y 8,2 , b) xxii y d) vi, del Estatuto de Roma. Con todo, la ya recordada falta de competencias penales-internacionales de estos Tribunales plantea una serie de condicionantes a esta tarea.

El primero es que los casos que por el momento han llegado ante estos Tribunales no parecen cubrir todos los tipos de crímenes sexuales contemplados en el catálogo del Estatuto de Roma, tal como sucede con el embarazo forzado que, en principio, está ausente en la jurisprudencia de ambos Tribunales. En cambio, otros crímenes sexuales como la esclavitud sexual y la prostitución forzada comienzan a plantearse en el diálogo birregional en el marco de situaciones de graves abusos sexuales, esclavitud y tráfico de personas a fines de explotación sexual.

El segundo condicionante se refiere a casos en los que los hechos podrían considerarse como uno de los tipos penales internacionales, pero que sin embargo han sido objeto de una calificación jurídica distinta por los Tribunales regionales, como sucede con el caso de la esterilización forzada. Además, los dos Tribunales han tenido también que enfrentarse a los problemas que suscita la llamada cláusula residual en relación con "otras formas de violencia sexual" por lo que respecta a la determinación de cuándo un acto tiene naturaleza sexual y reúne una gravedad comparable para ser considerado un crimen de violencia sexual.

\section{A. Un catálogo de crímenes sexuales sólo parcialmente cubierto: Las cuestiones suscitadas por el embarazo forzado, la esclavitud sexual y la prostitución forzada}

Tal como se ha anticipado, la falta de competencia penales de la CIDH y el TEDH unida a la especificidad de los elementos objetivo y subjetivo propios de cada uno de los crímenes internacionales de violencia sexual que recoge el catálogo de crímenes del Estatuto de Roma dan lugar a que, en principio, no resulte posible encontrar ejemplos de todos los tipos penales de dicho catálogo en su jurisprudencia. Tal es el caso del crimen de embarazo forzado, cuya ausencia se explica en función del dolo especial que requiere en cuanto al confinamiento de una mujer a la que se haya dejado embarazada a la fuerza para modificar la composición étnica de una población o cometer otras violaciones graves del derecho internacional. A ello se suma la mención específica en el texto del Estatuto de Roma de que esta definición de embarazo forzado en modo alguno afecta a las normas internas relativas al embarazo. En consecuencia, los casos en los que se haya denegado o dificultado el acceso al aborto resultante de una violación, incluso aunque se haya producido algún tipo de internamiento de la 
mujer embarazada, no podrían considerarse crímenes de violencia sexual de embarazo forzado. Tal es el supuesto de hecho al que se refiere el caso P. y S. contra Polonia (2012), con independencia de que el TEDH estableciese en su sentencia la violación de los arts. 8, 5.1 y 3 del Convenio de Roma ${ }^{128}$.

Por lo que se refiere a la esclavitud sexual, si bien, como veremos a continuación, este crimen se plantea junto con la prostitución forzada en el marco del tráfico de personas para explotación sexual, el caso pendiente ante la CIDH, López Soto y otros contra Venezuela, parece reunir los elementos objetivo y subjetivo necesarios para su comisión por relación a actos de violencia sexual infringidos por un particular ${ }^{129}$. De hecho, la ComisiónIDH y las representantes de la víctima han pedido ante la CIDH que se califique de esclavitud sexual las repetidas formas de violencia y violación sexual de las que fue objeto Linda Loaiza López Soto durante los cuatro meses que estuvo retenida contra su voluntad por un particular. En este sentido, como la ComisiónCDI señaló en su Informe, además de resultar acreditados los actos de violencia sexual de los que esta mujer fue víctima de forma continuada a lo largo de todo el periodo de su retención, concurren las circunstancias señaladas en la jurisprudencia penal internacional que sirven para establecer la existencia de un elemento de esclavitud, ya que tales actos "tenían como propósito lograr la humillación de la víctima y tener un completo dominio sobre ella que determinó la relación de poder ejercida por su agresor" ${ }^{\prime 30}$.

Ahora bien, como acabamos de anticipar, la esclavitud sexual y la prostitución forzada aparecen principalmente vinculadas en el ámbito birregional al tráfico de personas para explotación sexual. Por lo que respecta a la $\mathrm{CIDH}$, hay que apuntar, por ejemplo, la sentencia en el caso Trabajadores de la Hacienda Brasil Verde contra Brasil (2016), en la que al hablar de las características del trabajo esclavo en Brasil, se constató que algunos trabajadores también sufren abuso sexual, aunque tales abusos no se planteasen en los hechos del caso $^{131}$. De la misma manera, en su Opinión Consultiva OC-21/14 sobre Derechos y Garantías de Niñas y Niños en el contexto de la migración y/o en necesidad de protección internacional, este Tribunal alertaba acerca de

128 TEDH, Caso P. and S. contra Polonia (2012), Sentencia de 30 de octubre de 2012.

129 Caso López Soto y otros vs. Venezuela con fecha de ingreso ante la CIDH de 2 de noviembre de 2016, tal como consta en la ficha técnica del caso.

${ }^{130}$ Informe No. 33/16, Caso 12.797. Fondo. Linda Loaiza López Soto y familiares. Venezuela. 29 de julio de 2016, párr.220. Tales circunstancias se concluyen de las condiciones en las que estuvo durante el periodo de cuatro meses: "privada de alimentación, siempre esposada o atada de alguna forma, sin libre acceso a higiene personal e íntima; que fue obligada a permanecer desnuda, a cocinar para su agresor, limpiar el apartamento que estaba lleno de sangre, a ingerir alcohol y drogas, a ver pornografía y a realizar estas prácticas con su agresor, entre otras condiciones" (párr.191) así como de que fuera mantenida privada de libertad bajo amenaza de muerte tanto para ella como para su familia, respecto de quiénes el agresor tenía sus datos de contacto" (parr.192).

${ }^{131}$ CIDH, Trabajadores de la Hacienda Brasil Verde contra Brasil, Sentencia de 20 Octubre de 2016 (Excepciones Preliminares, Fondo, Reparaciones y Costas), párr.114.

Araucaria. Revista Iberoamericana de Filosofia, Política, Humanidades y Relaciones Internacionales, año 20, $\mathrm{n}^{\circ} 40$. Segundo semestre de 2018. Pp. 511-575. ISSN 1575-6823 e-ISSN 2340-2199 doi: 10.12795/araucaria.2018.i40.23 
la especial vulnerabilidad a ser víctimas de trata para la explotación sexual de los menores migrantes (más aún las niñas), no acompañados o separados de su familia que se encuentran fuera de su país de origen ${ }^{132}$. Estas referencias resultan por tanto indicativas de las circunstancias en las que, entre otras, pueden llegar a plantearse casos de esclavitud sexual o prostitución forzada ante la CIDH.

Por relación al TEDH, aunque el mismo ha reconocido que su jurisprudencia en relación con el art. 4 del ConvencionEDH (prohibición de esclavitud, servidumbre y trabajo forzado) es escasa, algunos de estos casos se refieren al tráfico de personas (mujeres) para ejercer la prostitución ${ }^{133}$. En concreto, el ya citado caso Rantseva contra Chipre y Rusia concierne al tráfico de chicas procedentes de países de Europa del Este para trabajar en cabarets en Chipre en un contexto en el que, como se recoge en la propia sentencia, la palabra "artista de cabaret" se había convertido en sinónimo de prostituta y tanto los informes del Comisionado del Consejo de Europa como de la Defensora del Pueblo de Chipre habían subrayado la gravedad del problema del tráfico y la explotación sexual de la que éstas eran objeto ${ }^{134}$.El otro caso, L.E. contra Grecia (2016), se suscita por relación al tráfico de mujeres africanas para el ejercicio de la prostitución (como sucede con la demandante de nacionalidad nigeriana) a las que se les facilitaba la entrada irregular en Grecia a cambio de contraer una duda elevadísima de dinero (40 $000 €$ ), cuya devolución quedaba garantizada a través de la realización de un rito de vudú y amenazas de dañar a sus familias ${ }^{135}$. Un tercer caso es el S.M. contra Croacia (2018), relativo a una mujer que era obligada a prostituirse en una red dirigida por un expolicia.

Con independencia de los derechos y obligaciones del ConvenioEDH conculcados por los Estados en cada uno de estos casos, nos interesa centrarnos en la calificación jurídica de los hechos a efectos de su consideración como crímenes de esclavitud sexual o prostitución forzada. En este sentido, si bien es verdad que el TEDH no se ha atrevido a pronunciase claramente, ofrece algunas claves para determinar la posible comisión de uno u otro.

Así, por lo que se refiere a la esclavitud forzada, en su sentencia en el caso Rantseva el Tribunal, después de referirse expresamente a la jurisprudencia del Tribunal penal internacional para la ExYugoslavia en la que se señala que el control de la sexualidad y el trabajo forzado son factores a tener en cuenta para determinar la existencia de un derecho de propiedad sobre una persona en relación a nuevas

${ }^{132}$ CIDH, Opinión Consultiva OC-21/14, de 19 de Agosto de 2014 solicitada por la República Argentina, la República Federativa de Brasil, la República del Paraguay y la República Oriental del Uruguay. Derechos y Garantías de Niñas y Niños en el contexto de la migración y/o en necesidad de protección internacional, párr.91.

133 Una lista de tales casos se puede consultar en Vladislava Stoyanova, "L.E. v. Greece: Human Trafficking and States' Positive Obligations", disposible en https://strasbourgobservers. com/2016/02/02/1-e-v-greece-human-trafficking-and-states-positive-obligations/

134 TEDH, Caso Rantseva contra Chipre y Rusia, Párrs. 3 y 199.

135 TEDH, Caso L.E. contra Grecia. Sentencia de 21 de enero de 2016. Párrs. 7 y 8 , 
formas contemporáneas de esclavitud, considera que el tráfico de personas se basa en el ejercicio de poderes relativos al derecho de propiedad ${ }^{136}$. Este reconocimiento implícito de que el tráfico de personas para el ejercicio de la prostitución sería un caso de esclavitud sexual, resulta obscurecido por razón de que el Tribunal estima innecesario identificar si el trato del que había sido objeto la victima constituía "esclavitud", "servidumbre" o "trabajo forzado" y se limite a concluir que el tráfico en sí mismo (en el sentido del art. 3(a) del Protocolo de Palermo y del art. 4(a) del Convenio del Consejo de Europa contra el tráfico de personas), entra dentro del ámbito de aplicación del art, 4 del ConvenioEDH ${ }^{137}$. De manera más escapista aún, en el caso L.E. contra Grecia remite a su jurisprudencia sobre la aplicación de dicho art. 4 en el contexto de la trata de seres humanos, pero omite pronunciarse sobre su calificación especifica ${ }^{138}$. Por tanto, a pesar de la falta de un pronunciamiento claro y expreso por parte del TEDH, parece concluirse que éste considera que el tráfico de una persona a efectos de explotación sexual constituiría esclavitud sexual cuando concurran las circunstancias que pongan de manifiesto el ejercicio de poderes propios del derecho de propiedad.

Tampoco se ha referido el Tribunal de forma expresa a los criterios para la calificación del tráfico de personas a efectos de explotación sexual como prostitución forzada, aunque esta cuestión se haya planteado en el caso S.M contra Croacia (2018), en el que el TEDH no avanza más de lo ya señalado acerca de la aplicación del art. 4 del ConvenioEDH al tráfico de personas. Más esclarecedoras resultan, en cambio, dos sentencias referentes a supuestos de trabajo forzado o servidumbre, sin explotación sexual. Son los casos: J y otros contra Austria (2017) y Chowdury y otros contra Grecia $(2017)^{139}$. En el primero, el TEDH se refiere a la prostitución forzada como un supuesto de trabajo forzado y considera que éste resulta determinado por la naturaleza de la relación entre la persona y empleador, y no por el tipo de actividad desarrollada, la legalidad o ilegalidad de la actividad según el derecho nacional o su reconocimiento como actividad económica ${ }^{140}$. Señala también que la conclusión del delito de tráfico no requiere necesariamente que se complete el delito del que sea objeto la víctima de dicho tráfico, citando expresamente dentro de la enumeración que incluye a título ejemplificativo a la prostitución forzada, el trabajo forzado y esclavitud ${ }^{141}$.

136 Párr. 281 en el que señala: "The Court considers that trafficking in human beings, by its very nature and aim of exploitation, is based on the exercise of powers attaching to the right of ownership. It treats human beings as commodities to be bought and sold and put to forced labour, often for little or no payment, usually in the sex industry but also elsewhere (...) It implies close surveillance of the activities of victims, whose movements are often circumscribed (...). It involves the use of violence and threats against victims, who live and work under poor conditions (...).

137 Párrs. 281 y 282.

138 Párrs. 58 y 64.

139 TEDH, Caso J. y otros contra Austria. Sentencia de 17 de enero de 2017 y caso Chowdury y otros contra Grecia. Sentencia de 30 de mayo de 2017.

140 Caso J y otros contra Austria (2017). Párrs. 9.

141 Ibídem, Párr.20. 
Añade además que el trabajo forzado y el tráfico de personas con ese objeto no se deben confundirse con la esclavitud, instituciones o prácticas similares, o la servidumbre, puesto que no todo trabajo forzado constituye tráfico de persona, ni todo tráfico es esclavitud, ya que, como aclara, el tráfico en sí mismo es un proceso preparatorio de las conductas prohibidas en el art 4 del Convenio ${ }^{142}$.

En esta misma línea, el TEDH recuerda en el segundo caso que el concepto de trabajo forzado lleva aparejado una idea de coerción física o mental y que la explotación a través del trabajo constituye uno de los aspectos del tráfico de personas $^{143}$. A este respecto el TEDH considera que cuando un empleador abusa de su poder o se aprovecha de la situación de vulnerabilidad de los trabajadores para explotarlos, no hay voluntariedad en la relación laboral, como sucede en el caso, puesto que se trataba de trabajadores en situación de irregularidad sin recursos y en riesgo de ser arrestados, detenidos y deportados ${ }^{144}$. A la vista de estas consideraciones parece poder concluirse que, en el marco de la prohibición del trabajo forzado del art. 4 del ConvenioEDH, el ejercicio de la prostitución en un supuesto de tráfico de personas podrá ser calificada de prostitución forzada, cuando haya una situación de explotación laboral derivada de la circunstancia de vulnerabilidad en la que se encuentre la persona.

En resumen, la jurisprudencia del TEDH por relación al tráfico de personas para explotación sexual es susceptible de dos comentarios de signo diferente. Uno es positivo en la medida en que los principios y criterios que el Tribunal europeo proporciona en aras a determinar la existencia y diferenciación entre los crímenes sexuales de esclavitud sexual y prostitución forzada suponen una aportación relevante al diálogo interregional en la medida en que podrán ser utilizados por la CIDH. Sin embargo, en un sentido negativo, hay que referirse a la total ausencia de consideración del elemento de violencia sexual, presente en los casos examinados a la vez que la falta de análisis desde una perspectiva de género. Son precisamente estas carencias y una postura más procesalista que garantista las que, como se ha señalado, están detrás de la inadmisibilidad de casos como G.J. contra España o la ceguera ante la violencia sexual presente en el caso C.N contra Reino Unido ${ }^{145}$, con las consecuencias que de ello se deriva para la protección de los derechos de las personas objeto del tráfico de personas a efectos de explotación sexual en Europa ${ }^{146}$.

142 Ibídem. Párr.40.

143 TEDH, Caso Chowdury y otros contra Grecia (2017). Párrs. 90 y 93.

144 Ibídem. Párrs. 96 y 97.

145 TEDH, Caso G.J. contra España. Decisión de 12 de junio de 2016 y C. N. contra Reino Unido, Sentencia de 13 de noviembre de 2012.

${ }^{146}$ Vid. Valentina Milano, “The European Court of Human Rights'Case Law on Human Trafficking in Light of L.E. v Greece: A Disturbing Setback?” en Human Rights Law Review, 4 (2017), pp.727 y $726-27$.

Araucaria. Revista Iberoamericana de Filosofia, Politica, Humanidades y Relaciones Internacionales, año 20, $\mathrm{n}^{\circ} 40$ Segundo semestre de 2018. Pp. 511-575. ISSN 1575-6823 e-ISSN 2340-2199 doi: 10.12795/araucaria.2018.i40.23 


\section{B. La calificación de la esterilización forzada como esterilización sin consentimiento y esterilización no consentida o involuntaria}

La esterilización forzada, entendida como la privación de la capacidad de reproducción biológica de una o más personas que no tenga su justificación en un tratamiento médico o clínico y se haya llevado a cabo sin el libre consentimiento de la víctima ${ }^{147}$, es otro de los crímenes internacionales de violencia sexual que se suscita en el análisis de la jurisprudencia de la CIDH y el TEDH. De hecho, tanto en América Latina como en Europa es posible encontrar ejemplos recientes o incluso actuales de políticas o prácticas de este tipo centradas en determinados colectivos, entre los que se encuentran mujeres pertenecientes a comunidades indígenas, minorías o en situación de exclusión, y las personas LGTB.

En el ámbito regional europeo, se han planteado ante el TEDH una serie de casos relativos a la esterilización de mujeres de etnia romaní en hospitales de Eslovaquia y la República Checa ${ }^{148}$. Todos ellos están relacionados con las eventuales secuelas de una política existente en la Checoslovaquia comunista desde los años setenta y responden a un mismo patrón de actuación conforme al cual la esterilización se llevó a cabo al practicar a las demandantes una operación de cesárea, momento en el que supuestamente se les solicitaba el consentimiento para proceder a esterilizarlas, sin que éstas fueran conscientes de las consecuencias de tal intervención a efectos de su futura capacidad de procreación.

En su análisis, el TEDH sigue una misma línea jurisprudencial que se articula en torno al principio de que la esterilización sin el consentimiento de un adulto en plenitud de facultades es incompatible con las exigencias del respeto a la libertad y dignidad humana y que tal hecho alcanza el nivel de gravedad suficiente para ser considerado un trato degradante en el sentido del art. 3 del Convenio de Roma. Igualmente, a la vista de la información aportada por el Comisionado para los derechos humanos del Consejo de Europa para Eslovaquia, considera que se ha producido una violación de la obligación positiva establecida por el art. 8 del Convenio, al no haber adoptado el Estado las salvaguardias legales efectivas para proteger la salud reproductiva, en particular, de las mujeres de origen romaní.

Sin embargo, el Tribunal no estima la violación del art. 14 del ConvenioEDH en conjunción con los arts. 3, 8 y 12, rechazando la existencia de una política organizada de esterilización de mujeres romanís, al considerar que las pruebas objetivas no eran suficientemente consistentes para convencerlo de que las esterilizaciones de las que habían sido objeto las demandantes formaran parte de

${ }_{147}$ Estatuto de Roma, Elementos de los Crímenes.

148 TEDH, Caso V.C. contra Eslovaquia. Sentencia de 8 de noviembre de 2011; Caso N.B contra Eslovaquia. Sentencia de 12 de junio de 2012. Caso I.G y otros contra Eslovaquia. Sentencia de 13 de noviembre de 2012; Caso R.K contra la República Checa. Decisión de 27 de noviembre de 2012.

Araucaria. Revista Iberoamericana de Filosofía, Política, Humanidades y Relaciones Internacionales, año 20, $\mathrm{n}^{\circ} 40$. Segundo semestre de 2018. Pp. 511-575. ISSN 1575-6823 e-ISSN 2340-2199 doi: 10.12795/araucaria.2018.i40.23 
una política organizada o que la conducta del personal del hospital respondiese intencionalmente a motivos raciales, sin perjuicio de que las deficiencias en la legislación y en la práctica nacional sobre esterilizaciones fuesen susceptibles de afectar, en particular, a los miembros de la comunidad romaní149. Esta falta de reconocimiento de la existencia de discriminación por motivos de raza dio lugar a la opinión disidente del juez Mijovic que consideró que, al establecer únicamente la violación de los arts. 3 y 8, el caso se reducía a lo individual, cuando en su opinión resultaba obvia la existencia de una política de Estado de esterilización de mujeres romanís durante el régimen comunista, cuyos efectos continuaban manifestándose en el periodo de los hechos ${ }^{150}$.

Tampoco analiza el TEDH la violación de los derechos de la demandante desde una perspectiva de género, aunque haga algunas consideraciones que puedan ser entendidas en esta clave, como la obligación del Estado de adoptar medidas destinadas a proteger en particular la salud reproductiva de las mujeres romanís, la referencia a la actitud "paternalista" del personal del hospital o el reconocimiento de que la incapacidad para procrear de la demandante como consecuencia de la esterilización repercutía muy negativamente en su posición de mujer viviendo dentro de una comunidad romaní ${ }^{151}$. Por esta razón, hay también que apuntar las críticas doctrinales sobre la falta de consideración de una posible discriminación interseccional, es decir aquella que se produce por la intersección de la discriminación por razón de género con otras variables constitutivas de la identidad, como en este caso la pertenencia a la minoría romaní152.

En suma, al considerar la esterilización sufrida por las demandantes como una "esterilización sin consentimiento informado" y únicamente desde la perspectiva de la salud reproductiva, el TEDH ignora primeramente el elemento de la violencia sexual perpetrada. Además, al no reconocer la existencia de una política de esterilización y la discriminación de las que las demandantes habían sido objeto en su condición de mujeres de etnia romaní, desconoce el carácter sistemático y generalizado de dichos hechos. De esta manera, a nuestro juicio de manera muy poco valiente, el TEDH ha optado claramente por excluir

149 TEDH, Caso V.C. contra Eslovaquia (2011), párr.177.

${ }^{150}$ Añadía el Juez Mijovic en su Opinión Disidente; "The fact that there are other cases of this kind pending before the Court reinforces my personal conviction that the sterilisations performed on Roma women were not of an accidental nature, but relics of a long-standing attitude towards the Roma minority in Slovakia. To my mind, the applicant was "marked out" and observed as a patient who had to be sterilised just because of her origin, since it was obvious that there were no medically relevant reasons for sterilising her. In my view, that represents the strongest form of discrimination and should have led to a finding of a violation of Article 14 in connection with the violations found of Articles 3 and 8 of the Convention".

151 Ibidem, párr. 114.

${ }^{152}$ Gwendolyn Albert/Marek Szilvasi, "Intersectional Discrimination of Romani Women Forcibly Sterilized in the Former Czechoslovakia and Czech Republic" en Health and Human Rights Journal 2(2017), p.23.

Araucaria. Revista Iberoamericana de Filosofia, Politica, Humanidades y Relaciones Internacionales, año 20, $\mathrm{n}^{\circ} 40$ Segundo semestre de 2018. Pp. 511-575. ISSN 1575-6823 e-ISSN 2340-2199 doi: 10.12795/araucaria.2018.i40.23 
los casos relativos a la esterilización de las mujeres romanís en hospitales de Eslovaquia de la calificación del crimen internacional de esterilización forzosa, con las consecuencias que de esta jurisprudencia pueda desprenderse en el futuro frente a prácticas similares.

En el sistema latinoamericano de protección de derechos humanos, sin perjuicio de la relevancia del caso Mamérita Mestanza (2000) ante la ComisiónIDH, vinculado a las esterilizaciones forzadas ocurridas en el marco del Programa de Planificación Familiar y de Salud Reproductiva, implementado en el Perú entre los años 1991 y $2000^{153}$, por el momento sólo ha llegado a la CIDH el caso V. contra Bolivia (2016), relativo la ligadura de las trompas de Falopio practicada a una mujer de nacionalidad peruana por un funcionario público en un hospital estatal. El caso reviste un gran interés a efectos del crimen internacional de esterilización forzosa, puesto que la CIDH no sólo tuvo que decidir si dicha esterilización era contraria a las obligaciones internacionales del Estado sobre la base de la Convención interamericana, sino que se pronuncia expresamente sobre la calificación jurídica de los hechos. Así, como la propia Corte recoge, por un lado, "tanto la Comisión como la representante catalogaron los hechos como una esterilización forzada, mientras que el Estado argumentó que dicha nomenclatura era propia del derecho penal internacional, por lo que en este caso debería la Corte referirse eventualmente a una esterilización sin consentimiento o involuntaria"154.

En su sentencia, la Corte constata la existencia de prohibiciones expresas respecto a las esterilizaciones forzadas o involuntarias establecidas en el marco del derecho penal internacional, aunque se centra en la diversa terminología que se ha utilizado en el ámbito de los derechos humanos por parte de organismos internacionales y regionales de derechos humanos, refiriéndose a: la esterilización sin consentimiento, esterilización no consentida, esterilización involuntaria, esterilización obligatoria y esterilización forzada. De entre todas ellas, señala que la esterilización sin consentimiento previo, libre, pleno e informado será considerada a efectos de esta sentencia como una "esterilización no consentida o involuntaria".

De esta manera, la CIDH al descartar la calificación de esterilización forzada excluye implícitamente la existencia de un crimen internacional, en el momento de la calificación de los hechos, tal como después hará de forma expresa al abordar las alegaciones de los violaciones a los artículos 8.1 (derecho a las garantías judiciales) y 25.1 (protección judicial), señalando expresamente señala que a diferencia de otros casos de su jurisprudencia que "trataban sobre

\footnotetext{
${ }^{153}$ ComisiónIADH, Caso María Mamérita Mestanza Chávez contra Perú, Informe nº71/03, de 10.10.2003 (Solución amistosa). Téngase también en cuenta el caso F.D. contra Chile, Informe $\mathrm{n}^{\circ} 42 / 14$, de 21.07.2014.

${ }^{154}$ CIDH, caso V. contra Bolivia, Sentencia de 30 de noviembre de 2016 (Excepciones Preliminares, Fondo, Reparaciones y Costas), Párr.204
}

Araucaria. Revista Iberoamericana de Filosofia, Política, Humanidades y Relaciones Internacionales, año $20, \mathrm{n}^{\circ} 40$. Segundo semestre de 2018. Pp. 511-575. ISSN 1575-6823 e-ISSN 2340-2199 doi: 10.12795/araucaria.2018.i40.23 
violaciones sexuales, muerte, malos tratos y afectaciones a la libertad personal en el marco de un contexto general de violencia contra las mujeres", en el presente caso, "según la prueba presentada, dicha esterilización no consentida no formó parte de una política estatal ni ocurrió en un conflicto armado o como parte de un ataque generalizado y sistemático contra la población civil"155.

Por tanto, plenamente consciente de la jurisprudencia del Tribunal europeo de la que da nota en varios lugares de su sentencia en un claro ejemplo de diálogo birregional, la $\mathrm{CIDH}$ sigue en principio la misma línea del TEDH al excluir la calificación de esterilización forzosa y considerarla un trato cruel, inhumano y degradante a efectos del artículo 5.1 y 5.2 del Pacto de San José ${ }^{156}$. Sin embargo, hay que destacar el que no utilice la misma terminología que el TEDH, sino que escoja la usada por el Relator Especial sobre el derecho de toda persona al disfrute del más alto nivel posible de salud física y mental, el Comité de Derechos Humanos y el Comité contra la Tortura. Esta opción está en consonancia con el análisis sensible a la perspectiva de género que hace la $\mathrm{CIDH}$, puesto que no sólo se plantea si la esterilización de la fue objeto la demandante supuso una incumplimiento de las obligaciones del Estado de respetar, garantizar y de no discriminar en relación a los derechos a la integridad personal, a la libertad personal, a la dignidad, a la vida privada y familiar, de acceso a la información, a fundar una familia, y al reconocimiento de la personalidad jurídica, sino que también examina si constituyó un acto de violencia contra la mujer ${ }^{157}$.

A este respecto, la CIDH considera que el caso supone una discriminación por motivos de sexo y género sobre el que opera la protección estricta del artículo 1.1 de la Convención IDH, en la medida en que "las esterilizaciones afectan de forma desproporcionada a las mujeres por el hecho de ser mujeres y con base en la percepción de su rol primordialmente reproductivo y de que no son capaces de tomar decisiones responsables sobre su salud reproductiva y la planificación familiar"158. Además, siguiendo lo señalado en la Convención de Belém do Pará, Declaración y en Plataforma de Acción de la Cuarta Conferencia Mundial sobre la Mujer y por el Comité para la Eliminación de la

155 Ibídem, Párr. 297.

156 Ibídem, Párr. 270.

157 Ibídem, Párr. 205.

158 Ibídem, Párrs. 252 y 243 en el que se precisa "En particular, la Corte advierte que el fenómeno de la esterilización no consentida está marcado por estas secuelas de las relaciones históricamente desiguales entre las mujeres y los hombres. Aunque la esterilización es un método utilizado como anticonceptivo tanto por mujeres como hombres, las esterilizaciones no consentidas afectan de forma desproporcionada a las mujeres exclusivamente por esta condición en razón que se les asigna socialmente la función reproductora y de planificación familiar Por otra parte, el hecho de que las mujeres son el sexo con la capacidad biológica de embarazo y parto, las expone a que durante una cesárea sea frecuente la ocurrencia de esterilizaciones sin consentimiento al excluirlas del proceso de adopción de decisiones informadas sobre su cuerpo y salud reproductiva bajo el estereotipo perjudicial de que son incapaces de tomar tales decisiones de forma responsable

Araucaria. Revista Iberoamericana de Filosofia, Politica, Humanidades y Relaciones Internacionales, año 20, $\mathrm{n}^{\circ} 40$ Segundo semestre de 2018. Pp. 511-575. ISSN 1575-6823 e-ISSN 2340-2199 doi: 10.12795/araucaria.2018.i40.23 
Discriminación contra la Mujer, los relatores especiales de las Naciones Unidas y el Comité de Derechos Humanos, considera que tal esterilización constituye un acto de violencia contra la mujer ${ }^{159}$.

En conclusión, tanto el TEDH primeramente, como después la CIDH en el marco del diálogo birregional, han excluido considerar la esterilización forzada de las que fueron objeto las mujeres de los casos analizados en su dimensión de crimen internacional y han optado por calificarlos de "esterilización sin consentimiento" o "esterilización no consentida o involuntaria" y considerarlos como tratos inhumanos, crueles y degradantes. Sin embargo, a diferencia del TEDH que se limita a un enfoque desde la óptica de los derechos reproductivos, la CIDH incorpora el elemento discriminatorio y de género, reconociendo su naturaleza de acto de violencia sexual contra la mujer.

\section{Los problemas de interpretación de "Otras formas de violencia sexual" en el marco del diálogo interregional}

La jurisprudencia de la CIDH y el TEDH ofrecen también ejemplos de las dificultades suscitadas por las llamadas "otras formas de violencia sexual" es decir actos distintos a los expresamente tipificados en el catálogo de crímenes sexuales del Estatuto de Roma, pero que presentan una gravedad comparable (la llamada cláusula residual). Como es sabido, estos problemas se refieren a establecer si un acto tiene naturaleza sexual y en segundo lugar si reúne el umbral de gravedad suficiente. Para ilustrar cómo se ha planteado esta cuestión en el marco del diálogo interregional, tomaremos como muestras la sentencia de la CIDH en el asunto del Penal Miguel Castro contra Peru (2006) y la sentencia del TEDH en el caso A, B y C contra Letonia (2016).

En la primera de estas sentencias, la CIDH tuvo que calificar y considerar a efectos de la ConvenciónIDH, la desnudez forzada de la que fueron objeto durante prolongados períodos los internos heridos en el Hospital de Policía como consecuencia de los hechos acaecidos en el llamado "Operativo Mudanza 1 " que tuvo lugar en el marco del conflicto armado entre grupos armados y agentes de las fuerzas policial y militar en Perú desde comienzos de la década de los ochenta hasta finales del año 2000.

La Corte consideró dichos actos como un "trato violatorio para su dignidad personal", enfatizando que dicha desnudez forzada tuvo características especialmente graves" para las seis mujeres internas que fueron sometidas a ese trato. A este respecto, el Tribunal precisa que "esas mujeres, además de recibir un trato violatorio de su dignidad personal, también fueron víctimas

159 Párr.251-255. Por consiguiente, la CIDH concluye que "el Estado incumplió su obligación de abstenerse de cualquier acción o práctica de violencia contra la mujer y velar por que las autoridades, sus funcionarios, personal y agentes e instituciones se comporten de conformidad con esta obligación, en contravención con el artículo 7.a) de la Convención de Belém do Pará". 
de violencia sexual, ya que estuvieron desnudas y cubiertas con tan solo una sábana, estando rodeadas de hombres armados, quienes aparentemente eran miembros de las fuerzas de seguridad del Estado. Por tanto, considera que "Lo que califica este tratamiento de violencia sexual es que las mujeres fueron constantemente observadas por hombres".

De esta manera, la CIDH, estima en la misma línea que la jurisprudencia de los Tribunales para la ExYugoslavia y Ruanda - no por lo que respecta a la CPI-, que la desnudez forzada es un acto de violencia sexual de gravedad comparable puesto que constata la concurrencia de los dos elementos necesarios. Así, primero señala que "la violencia sexual se configura con acciones de naturaleza sexual que se cometen en una persona sin su consentimiento, que además de comprender la invasión física del cuerpo humano, pueden incluir actos que no involucren penetración o incluso contacto físico alguno" ${ }^{160}$. Segundo, considera que dicho acto reúne el umbral de gravedad suficiente ya que "les ocasionó grave sufrimiento psicológico y moral".

La sentencia del TEDH en el caso A, B y C contra Letonia (2016) se plantea en un contexto completamente distinto, en el que este Tribunal tiene que pronunciarse acerca de la violación del art. 8 del Convenio de Roma por relación a la obligación positiva del Estado de asegurar la efectiva investigación criminal de una serie de actos de los que habían sido objeto un grupo de niñas por parte de su entrenador en una escuela pública de deportes en Riga.

El TEDH analiza los hechos, en atención a su diferente gravedad y consecuencias sobre la vida privada de las demandantes, comenzando por los tocamientos "como por accidente" en las partes íntimas de dos de las niñas en los vestidores y el entrar en la sauna cuando una de las niñas estaba medio desnuda y ridiculizarla. Para ello, tomando como referencia su jurisprudencia, establece una gradación, situando en un primer nivel de gravedad la violación y el abuso sexual de menores ${ }^{161}$, al que seguirían los actos que, sin suponer violencia física, supongan una amenaza potencial a la salud física y mental del menor ${ }^{162}$. Y ya, en tercer lugar se refiere a actos de menor gravedad entre individuos que, sin embargo, puedan violar la integridad sicológica, mencionando el caso Söderman, relativo a los intentos de un padrastro de filmar a su hijastro de catorce años desnudo en el baño y cuyos principios estima aplicables al caso. A este respecto, el TEDH considera que la vía penal no sería necesariamente la única manera a través de la cual el Estado puede cumplir las obligaciones derivadas del art. 8, si existen remedios adecuados en el ámbito civil. Siguiendo también el caso Söderman, el Tribunal destaca que el proponer a una de las niñas que compartiesen la misma cama durante un viaje a

\footnotetext{
${ }^{160}$ La cursiva es nuestra.

161 Párr. 148.

162 Párr. 159 y 151.
}

Araucaria. Revista Iberoamericana de Filosofia, Politica, Humanidades y Relaciones Internacionales, año 20, $\mathrm{n}^{\circ} 40$ Segundo semestre de 2018. Pp. 511-575. ISSN 1575-6823 e-ISSN 2340-2199 doi: 10.12795/araucaria.2018.i40.23 
Lituania no supuso ningún tipo de violencia física o abuso. Por tanto, el TEDH concluye considerando que es no capaz de discernir si tales actos tienen tal gravedad como para determinar que una investigación criminal hubiera sido la única manera que el Estado hubiera tenido para cumplir la obligación positiva impuesta por el art. 8 de la Convención.

En segundo lugar, el TEDH se pronuncia acerca del masaje en las piernas a las niñas en la sauna cuando estaban desnudas y de los eventuales tocamientos de sus partes íntimas. Considera que su gravedad es mayor, aunque no resulten equiparables a la del caso X y Y contra Países Bajos relativo a la violación de una niña con discapacidad. El Tribunal destaca la importancia que atribuye a que tales hechos tuvieran lugar en el contexto de una relación de confianza y autoridad derivada de la posición del entrenador como educador con relación a las demandantes, que eran personas vulnerables debido a su edad. Por tanto, estima la posición del Estado de que resultaba necesaria una investigación criminal en el plano nacional que, como se destaca, se centró en determinar si tales hechos habían tenido una intención sexual, según lo establecido en la sección 162 del Código penal letón. A este respecto, aclara que no está persuadido que la no consideración de ciertos elementos de prueba en el desarrollo de la investigación llevada a cabo en el plano interno, aducida por las demandantes, hubiesen cambiado la conclusión a la que se llegó en el curso de tal investigación de que no concurría el requerido elemento subjetivo y por tanto al cierre de la investigación ${ }^{163}$. En consecuencia, estima que no se ha producido violación del art. 8 del Convenio.

Como se pone de manifiesto, aun salvando las diferencias derivadas del contexto en el que se producen los hechos, el enfoque del TEDH es muy distinto al de la CIDH en función de los criterios que utiliza para determinar la naturaleza sexual del acto y su gravedad: la concurrencia de un elemento subjetivo de haber realizado el acto con intención sexual y que haya violencia física o abuso. Por esta razón, además de las críticas de las que esta sentencia ha sido objeto desde la perspectiva de la protección de los menores de la violencia sexual y la total ausencia de una perspectiva de género ${ }^{164}$, resulta claro que supone también un precedente restrictivo a la hora de tener en cuenta "otras formas de violencia sexual" que se puedan plantear en su casuística como crímenes de violencia sexual.

\footnotetext{
163 Párr. 177
}

164 Yaiza Janssens, “A, B and C v. Latvia: gender-blindness and trivialisation of indecent acts against adolescent girls", disponible en https://strasbourgobservers.com/2016/05/20/a-b-and-c-vlatvia-gender-blindness-and-trivialisation-of-indecent-acts-against-adolescent-girls/ 


\section{Conclusiones}

La investigación y sanción de la violencia sexual es una labor compartida por los órganos jurisdiccionales que conforman el sistema de justicia penal internacional, a la que también se han incorporado progresivamente el Tribunal Europeo de Derechos Humanos y la Corte Interamericana. Ambos tribunales, sin entrar a dirimir la responsabilidad penal individual, han generado una jurisprudencia creciente relativa a vulneraciones graves de los derechos humanos constituidos por actos de violencia sexual, entablando un diálogo jurisdiccional interregional por partida doble.

En primer lugar, se ha producido un intercambio expreso entre ellos, consistente en el recurso a la labor desarrollada por el otro como fórmula para reforzar o justificar las propias decisiones sobre esta materia. En este sentido la CIDH se ha mostrado mucho más receptiva y atenta a la labor desarrollada por el TEDH que a la inversa. Sin embargo, una valoración comparada de la jurisprudencia de ambos Tribunales en los casos de violencia sexual pone de manifiesto que, si bien el TEDH aparentemente parece seguir liderando este diálogo interregional, en el que ha llevado a cabo una labor pionera, sobre todo en relación a la violencia sexual en el ámbito doméstico o a su consideración de tortura, la CIDH estaría en estos momentos avanzando respecto al análisis más conservador efectuado por su homólogo europeo. Así, la CIDH ha ido incorporando en el razonamiento de sus sentencias de forma clara y explícita una perspectiva de género que, al tener en cuenta el elemento discriminatorio de la violencia sexual, permite la protección de los derechos de las víctimas de esta particular forma de violencia desde una aproximación holística que comprende todos los contextos y situaciones en la que se hallan tanto las víctimas como los victimarios.

Resulta pues necesario que el diálogo interregional sobre violencia sexual devenga auténticamente bidireccional y que, superando posibles prejuicios eurocéntricos, el TEDH tome consciencia de la postura más comprometida de la CIDH para que, de la misma manera que ésta considera que el deber de no discriminación contenido en el art. 1.1 del Pacto de San José se proyecta sobre la obligación estatal de diligencia debida en la investigación y sanción de la violencia sexual, el Tribunal Europeo aplique el art. 14 del Convenio de Roma a todo tipo de violencia sexual. Este enfoque le permitiría al TEDH apreciar el carácter sistemático y generalizado que lleva aparejada la violencia sexual en determinados tipos de crímenes que normalmente se cometen como parte de una política, caso de la esterilización forzosa, superando así un enfoque hasta ahora excesivamente tímido y limitado. Pero, sobre todo, la consideración del elemento discriminatorio resulta, en nuestra opinión, necesario para responder adecuadamente a algunos de los supuestos más graves y recurrentes de 
violaciones de derechos humanos en las sociedades europeas por la especial vulnerabilidad e invisibilidad de sus víctimas que conllevan el uso de la violencia sexual, tal y como sucede en el tráfico de personas para explotación sexual. En este mismo orden de cosas, el TEDH debería ser más valiente y, tomando en consideración el elemento de violencia sexual siempre presente en estos casos, calificarlos de esclavitud sexual o prostitución forzada en virtud del art. 4 del Convenio de Roma.

En segundo lugar, junto al diálogo expreso ambos tribunales vienen llevando a cabo un diálogo tácito o subliminal, que a nuestro entender se hace especialmente patente en una jurisprudencia gemela en la que han abordado en paralelo tres aspectos cruciales, a saber: la calificación de la violencia sexual como un crimen internacional de tortura cuando concurre la sistematicidad o el elemento contextual y su consiguiente prohibición en tanto que norma de ius cogens; la violación como el crimen sexual por antonomasia que, partiendo de una definición y elementos comunes, se ha ido actualizando para dar cabida a la violación intrafamiliar y a la violación padecida por hombres; y la categorización de otros crímenes y formas de violencia sexual contemporánea.

Con todo, a nuestro juicio para comprender el alcance y las consecuencias de este rico y complejo diálogo jurisdiccional interregional hemos de tener presente que no tiene solo un carácter puramente horizontal, sino que presenta también una dimensión vertical. Esta dimensión vertical se proyecta de forma ascendente con los Tribunales penales ad hoc y la Corte Penal Internacional, que constituyen un referente obligado en el tratamiento sustantivo y procedimental de la investigación y sanción de la violencia sexual. Pero también se proyecta de forma descendente en el plano interno con los tribunales nacionales. De hecho tanto el TEDH como la Corte interamericana son la última ratio de la que disponen las víctimas de los crímenes sexuales para que se les reconozca en la práctica el derecho a la verdad, a la justicia y a la reparación que en primera instancia se le ha negado. La labor de ambos tribunales no consiste solo en proporcionarles amparo cuando el estado o bien no ha actuado con la diligencia debida o bien se ha transformado en un segundo agresor, sino que tiene una vocación transformadora de las sociedades y del derecho interno. En la lucha contra la impunidad de la violencia sexual alcanza pleno sentido el aforismo de Legaz y Lacambra que cada día nos recuerda que "el Derecho o sirve para la vida o no sirve para nada". 


\section{Referencias bibliográficas:}

Gwendolyn Albert/Marek Szilvasi, "Intersectional Discrimination of Romani Women Forcibly Sterilized in the Former Czechoslovakia and Czech Republic" en Health and Human Rights Journal 2(2017), pp. 23-34.

Rosa A. Alija Fernández, "La violencia doméstica contra las mujeres y el desarrollo de estándares normativos de derechos humanos en el marco del Consejo de Europa", en Revista General de Derecho Europeo 24 (2011), p. 11

Kai Ambos, María Laura Bohm, “Tribunal Europeo de Derechos Humanos y Corte Interamericana de Derechos Humanos. ¿Tribunal tímido vs. tribunal audaz?, en Sistema Interamericano de Protección de los Derechos Humanos y Derecho Penal Internacional- Tomo II, Montevideo: Fundación Konrad Adenhauer, Universidad de Gottingen, 2011, pp. 43-69.

American Society of International Law, Charting new frontiers in international law, Proceedings of the 110th annual meeting, March 30-April 2, 2016, Washington, DC.

Francisco Javier Ansuátegui Roig, "Human Rights and Judicial Dialogue between America and Europe: Toward A New Model Of Law? " en The Age of Human Rights Journal”, 6 (2016) pp. 24-41.

Kerstin Blome, Wallflower or Essential Constituent? The Inter-American Court of Human Rights' Role in an Emerging International Judicial Human Rights System, SGIR 7th Pan-European International Relations Conference, (Section 32: International Institutions, Global Politics, and Law Panel VIII: Towards a Global Network of Courts ?) September 2010. Alison Brysk, "Introducción: violencia de género y relaciones internacionales" en Revista CIDOB d'Afers Internacionals, 117 (2017), pp.7-28

Laurence Burgorgue-Larse., Nicolás Montoya Céspedes, "El diálogo judicial entre la Corte Interamericana y la Corte Europea de Derechos Humanos", en Protección Multinivel de Derechos Humanos. Manual, G. Rodrigo/R. Ureña/A Torres (coords.), 2013.

Diana Marcela Bustamante Arango, "La violencia sexual como tortura. Estudio jurisprudencial en la Corte Interamericana de Derechos Humanos", en Revista de la Facultad de Derecho y Ciencias Políticas, 121 (2014), pp. 461-502.

Violeta Cánoves, "Como la cigarra. Notas sobre la violencia sexual, jurisprudencia y Derechos Humanos," en 2 Revista Jurídica de la Universidad de Palermo, (2011), p. 104.

Antonio Cassese, Five Masters of International Law: Conversations with RJ Dupuy, E. Jiménez de Aréchaga, R. Jennings. L. Henkin and O. Schachter, Oxford Hart Publishing, 2011. 
Emanuela Cardoso Onofre De Alencar, "Mujeres y estereotipos de género en la jurisprudencia de la Corte Interamericana de Derechos Humanos" en Eunomía. Revista en Cultura de la Legalidad, 9 (2016), pp. 26-48.

Laura Clérico/Celeste Novelli, "La violencia contra las mujeres en las producciones de la comisión y la Corte Interamericana de Derechos Humanos" en Estudios Constitucionales 1 (2014), pp. 15-70.

Comisión Interamericana de Derechos Humanos, Acceso a la justicia para las mujeres víctimas de violencia en las Américas, Washington, OEA, 2007.

Council of Europe, Equal Access to Justice in EHRC Case-law on Violence against Women, 2015.

Council of Europe/European Court of Human Rights \& Inter-American Court of Human Rights, Dialogue Across the Atlantic: Selected Case-Law of the European and Inter-American Human Rights Courts, Oisterwijk, Wolf Legal Publishers (WLP), 2015.

Javier Chinchón Álvarez, Derecho Internacional y transiciones a la democracia y la paz: hacia un modelo para el castigo de los crímenes pasados en la experiencia iberoamericana, Parthenon, 2007.

Javier Chinchón Álvarez., "El concepto de impunidad a la luz del Derecho Internacional. Una aproximación sistémica desde el Derecho Internacional penal y el Derecho Internacional de los Derechos Humanos" en Revista Electrónica de Estudios Internacionales 24 (2012).

Julieta Di Corleto, "La valoración de la prueba en casos de violencia de género", en Garantías constitucionales en el proceso penal, Plazas, Florencia y Hazan Luciano, 2015, pp. 1-16.

Julieta Di Corleto/ Maria L. Piqué., "Pautas para la recolección y valoración de la prueba con perspectiva de género", en Género y Derecho Penal. Homenaje al Prof. Wolfgang Schöne, José Hurtado Pozo (ed.), 2017, en especial pp. 415-423.

Javier Dondé Matute., "El concepto de impunidad: leyes de amnistía y otras formas estudiadas por la Corte Interamericana de Derechos Humanos", en Sistema Interamericano de protección de los derechos humanos y Derecho Penal Internacional, Gisela Elsner (ed.), Grupo Latinoamericano de Estudio sobre Derecho Penal Internacional, Fundación K. AdenauerStiftung, 2010, pp. 263-295.

Madeleine Eklund, Violence Against Women as a Violation of the European Convention on Human Rights: Due Diligence and State Responsibility for Violence against Women by Private Actors (Bachelor's thesis), Örebro, Örebro Univertitet, 2016.

Mónica Feria Tinta., "Primer caso internacional sobre violencia de género en la jurisprudencia de la Corte Interamericana de Derechos Humanos: el caso del penal Miguel Castro Castro, un hito histórico para Latinoamérica", 3 Revista CEJIL (2007), pp. 30-45. 
Eduardo Ferrer McGregor, "What do we mean when we talk about judicial dialogue?: Reflections of a judge of the Inter-American Court of Human Rights" en Harvard Human Rights Journal 30 (2017), pp. 89-129.

Andreas Follesdal/Geir Ulfstein, The judicialization of international law: a mixed blessing, Oxford, Oxford University Press, 2018.

Joaquín García Roca, Humberto Nogueira Alcalá, Rafael Bustos Gisbert, "La comunicación entre ambos sistemas y las características del diálogo", (en Joaquín García Roca, Pablo Antonio Fernández, Pablo Santolaya, Raúl Canosa, eds: El diálogo entre los Sistemas Europeo y Americano de Derechos Humanos, Cizur Menor, Thomson Reuters, 2012.

Baltasar Garzón, “Avances en la jurisprudencia internacional en violencia sexual contra mujeres en conflictos armados", en The Journal Jurisprudence, 15 (2012), pp. 443-472.

Virginia Petrova Georgieva, "La "judicialización": una nueva característica del sistema jurídico internacional" en Anuario Mexicano de Derecho Internacional, 2015, pp.3-45.

Alicia Gil Gil., "Delitos contra la comunidad internacional", en Comentarios prácticos al Código Penal, M. Gómez Tomillo (dir.), vol. 6. 2015, pp. 741 a 830 .

Tania Groppi, Anna Maria Lecis Cocco-Ortu, "Las referencias recíprocas entre el Tribunal Europea y la Corte Interamericana de Derechos Humanos: ¿de la influencia al diálogo?” en Revista de Derecho Político-UNED, 91(2014).

Lee Hasselbacher, "State Obligations Regarding Domestic Violence: The European Court of Human Rights, Due Diligence, And International. Legal Minimums of Protection" en Northwestern Journal of International Human Rights, 2 (2010), pp.190-215.

Camille Jacquemin, Gender Violence" in the Case-Law of the European Court of Human Rights, Master dissertation, Faculty of Law, Ghent, University of Ghent Academic year 2012-13.

Yaiza Janssens, "A, B and C v. Latvia: gender-blindness and trivialisation of indecent acts against adolescent girls", disponible en https:// strasbourgobservers.com/2016/05/20/a-b-and-c-v-latvia-genderblindness-and-trivialisation-of-indecent-acts-against-adolescent-girls/.

Eduardo Jiménez de Aréchaga, E., "La costumbre como fuente del Derecho Internacional", en Estudios de Derecho Internacional. Homenaje al Profesor Miaja de la Muela, Tecnos, 1979, pp. 375-402.

José María Larralde., "El Tribunal Europeo de Derechos Humanos y la protección de los derechos de las mujeres" en Criterio Jurídico Garantista 7 (2012), pp.58-79. 
Isabel Lirola Delgado/Magdalena Martín Martínez, Crímenes Internacionales de violencia sexual y conflictos armados, Cizur Menor, Thomson Reuters, 2016.

Catharine A. MacKinnon en "Rape redefined" Harvard Law and Politics Review 10 (2016), pp. 431-477.

Catharine A. MacKinnon "Rantsev. V. Chipre \& Rusia, App. no 25965/04 (Eur. Ct. H.R. Ene 7, 2010”, en Anuario de Derechos Humanos 7 (2011), p. 110, disponible en https://anuariocdh.uchile.cl/.

Javier Mariezcurrena,/Pablo Rovatti "Valoración de la prueba de la violencia sexual en la jurisprudencia de la Corte Interamericana de Derechos Humanos,", en La Constitución y sus garantías. A 100 años de la Constitución de Querétaro de 1917, Eduardo, Ferrer MacGregor, Rogelio Flores Pantoja (coords), 2017, pp. 541-574.

Clare McGlynn, Rape, "Torture and the European Convention on Human Rights" en International and Comparative Law Quarterly, 3 (2009), pp. 565-595.

Magdalena Martín Martínez/ Isabel Lirola Delgado., "Los crímenes de violencia sexual en el Derecho Internacional Humanitario, ICIP, Informes 8/2013, disponible en http://icip.gencat.cat/web/.content/continguts/publicacions/ documents_i_informes/arxius/crimenes_de_violencia_sexual.pdf;

Graciela Medina, "La violencia contra las mujeres en la jurisprudencia del Tribunal Europeo de Derechos Humanos", en Cuestiones de interés jurídico del Instituto de Derecho Iberoaméricano, (20015), disponible en dibe.org/cuestiones-de-interes-juridico/la-violencia-contra-las-mujeresen-la-jurisprudencia-del-tribunal-europeo-de-derechos-humanos/

Valentina Milano, "The European Court of Human Rights'Case Law on Human Trafficking in

Light of L.E. v Greece: A Disturbing Setback?” en Human Rights Law Review, 4 (2017), pp. 701-727

Yennesit Palacios Valencia, "Tribunales Internacionales de Protección de Derechos Humanos en caso de crímenes internacionales" en REcorDIP, 2 (2013), pp. 1-33.

Oscar Parra Vera, “Algunos aspectos procesales y sustantivos de los diálogos recientes entre la Corte Interamericana de Derechos Humanos y el Tribunal Europeo de Derechos Humanos", en Pablo Santolaya/I. Wences (coords.), La América de los Derechos, Centro de Estudios Políticos y Constitucionales, 2016, pp. 565-606.

"La jurisprudencia de la Corte Interamericana respecto a la lucha contra la impunidad: algunos avances y debates" en Revista Jurídica de la Universidad de Palermo, 1 (2012), pp.5-50. 
María Teresa Ponte Iglesias, "Protección de las mujeres indígenas frente a la violencia y acceso a la justicia: una visión desde el Derecho Internacional" (en Alexandra Tomaselli, Marzia Rosti, Roberto Cammarata \& Chiara Scardozzi, eds.: Desafios de los pueblos indígenas en su participación politica y socio-económica: recursos naturales, género, educación y propiedad intelectual, Bolzano, Eurac Research, 2017), pp. 299-324.

Sara Willians/ Hannah Woolaver, "The role of the Amicus curiae before International Criminal Tribunals" en International Criminal Law Review 6 (2006), pp. 151-189.

Ivana Radačić, "Rape Cases in the Jurisprudence of the European Court of Human Rights: Defining Rape and Determining the Scope of the State's Obligations", en European Human Rights Law Review, (2008), pp.357375.

Carolina Rodríguez Bejarano, "El estándar de la prueba indiciaria en los casos de violencia sexual ante la Corte Interamericana de Derechos Humanos", en Memorando de Derecho, 2011, pp. 23-36.

Bruno Rodríguez Reveginno, "Espacios de dialogo entre la Corte Interamericana de Derechos Humanos y el Tribunal Europeo de Derechos Humanos" en Revista Internacional de Derechos Humanos 7 (2017), pp. 15-37.

Naomí Roth -Arriaza, "After Amnisties are gone: Latin American National Courts and new contours of the fight against impunity" en Human Rights Quaterly, 37 (2015), pp. 341-382.

Celeste Saccomano, "El feminicidio en América Latina:¿vacío legal o déficit del Estado de derecho?", Revista Cidob d'Afers Internacionals, (117) 2017 ,

James A. Sweeney, J.A., The European Court of Human Rights in the PostCold War Era. Universality in transition, Routledge, 2013, pp. 51-78

Anne-Marie Slaughter, "A Typology of Transjudicial Communication" en University of Richmond Law Review, 1 (1994), pp. 99-127.

Lorena P. A. Sosa, "Inter-American case law on femicide: Obscuring intersections?" en Netherlands Quarterly of Human Rights, 2 (2017), pp. 85-103.

Patricia Tarre Moser/Salvador Leyva Morelos-Zaragoza, "Violencia sexual contra el hombre: avance jurisprudencial de la Corte Interamericana de los Derechos Humanos", en Revista Internacional de Derechos Humanos, 5 (2015), pp, 69-90.

Camila Troncoso, "Caso M.G.C. vs. Rumania", en Revista de Ciencias Penales 2 (2016), pp. 301-312.

Tatsiana Ushakova, "La protección contra la violencia de género en el sistema interamericano de Derechos Humanos" en Dereito 22 (2013), pp. 53-86. 
Carla Zoethout, "The European Court of Human Rights and Transnational Judicial Dialogue. References To Foreign Law and the Quest for Justification", en Vienna J. on Int'l Const. L., 3 (2015), pp.398-416. 


\section{JURISPRUDENCIA (por orden cronológico)}

\section{Corte Interamericana de Derechos Humanos}

-Caso Velásquez-Rodríguez contra Honduras, Sentencia de 29 de julio de 1988 (Fondo)

-Caso Masacre Plan de Sánchez contra Guatemala Penal, Sentencia de 29 de abril de 2004 (Fondo)

-Caso Almonacid Arellano y otros contra Chile, sentencia de 26 de septiembre de 2006

- Caso Penal Miguel Castro Castro contra Perú, Sentencia de 25 de noviembre de 2006 (Fondo, Reparaciones y Costas)

-Caso Bueno Alves contra Argentina, Sentencia de 11 de mayo de 2007

-Caso González y otras (“Campo Algodonero"), contra Méjico Sentencia de 16 de Noviembre de 2009 (Excepción Preliminar, Fondo, Reparaciones y Costas)

-Caso de la Masacre de las Dos Erres contra Guatemala, Sentencia de 24 de noviembre de 2009 (Excepción Preliminar, Fondo, Reparaciones y Costas);

-Caso Fernández Ortega y otros contra Méjico, Sentencia de 30 de agosto de 2010 (Excepción Preliminar, Fondo, Reparaciones y Costas)

-Caso Rosendo Cantú y otra contra Méjico, Sentencia de 31 de agosto de 2010, (Excepción Preliminar, Fondo, Reparaciones y Costas)

-Caso Masacre de Rio Negro contra Guatemala, Sentencia de 4 de septiembre de 2012 (Excepción Preliminar, Fondo, Reparaciones y Costas)

-Caso Masacres de El Mozote y lugares aledaños contra El Salvador, Sentencia de 25 de octubre de 2012 (Fondo, Reparaciones y Costas)

-Caso J. contra Perú, Sentencia de 27 de noviembre de 2013 (Excepción Preliminar, Fondo, Reparaciones y Costas)

-Caso de Rodríguez Vera y otros ("Desaparecidos del Palacio de Justicia") contra Colombia, Sentencia de 14 de noviembre de 2014.

-Caso Espinoza González contra Perú, Sentencia de 20 de noviembre de 2014 (Excepciones Preliminares, Fondo, Reparaciones y Costas)

-Caso Veliz Franco y otros contra Nicaragua, Sentencia de 19 de Mayo de 2014 (Excepciones Preliminares, Fondo, Reparaciones y Costas)

Caso Trabajadores de la Hacienda Brasil Verde contra Brasil, Sentencia de 20 Octubre de 2016

(Excepciones Preliminares, Fondo, Reparaciones y Costas)

-Caso Yarce y otras contra Colombia, Sentencia 22 noviembre 2016

-Caso I.V. contra Bolivia, Sentencia de 30 de noviembre de 2016 (Excepciones Preliminares, Fondo, Reparaciones y Costas) 
-Caso Favela Nova Brasilia contra Brasil, Sentencia de 16 de febrero de 2017

(Excepciones Preliminares, Fondo, Reparaciones y Costas);

-Caso V.R.P., V.P.C. y otros contra Nicaragua, Sentencia de 8 de marzo de 2018

(Excepciones Preliminares, Fondo, Reparaciones y Costas)

-Opinión Consultiva OC-21/14, de 19 de Agosto de 2014 solicitada por la

República Argentina, la República Federativa de Brasil, la República del Paraguay y la República Oriental del Uruguay. Derechos y Garantías de Niñas y Niños en el contexto de la migración y/o en necesidad de protección internacional

\section{Tribunal Europeo de Derechos Humanos}

-Caso X e Y contra Países Bajos, Sentencia de 26 de marzo de 1985

-Caso C.R. v The United Kingdom, Sentencia de 22 de noviembre de 1995

-Caso S.W. v. The United Kingdom, Sentencia de 22 de noviembre de 1995

-Caso Aydin contra Turquía, Sentencia de 25 de septiembre de 1997

-Caso Y.F contra Turquía, Sentencia de 22 de julio de 2003

-Caso M.C. contra Bulgaria, Sentencia de 4 de diciembre de 2003

-Caso Abulsamet Yaman contra Turquía, Sentencia de 2 de noviembre de 2004

-Caso Menesheva contra Rusia, Sentencia de 9 de marzo de 2006

-Caso Maslova contra Rusia, Sentencia de 24 de enero de 2008

-Caso Juhnkev contra Turquía, Sentencia de 13 de mayo de 2008

-Caso Bevacqua contra Bulgaria, Sentencia de 12 de junio de 2008

-Caso Salmanoglu contra Turquía, Sentencia de 17 de marzo de 2009

-Caso Rantseva contra Chipre y Rusia, Sentencia de 7 de junio de 2010

-Caso Opuz contra Turquía, Sentencia de 9 de junio de 2009

-Caso A. contra Croacia, Sentencia de 14 de octubre de 2010

-Caso Yazgül Yilmaz contra Turquía, Sentencia de 1 de febrero de 2011

-Caso V.C. contra Eslovaquia, Sentencia de 8 de noviembre de 2011

-Caso de E. y otros contra el Reino Unido, Sentencia de 26 de noviembre de 2011

-Caso P.M. contra Bulgaria, Sentencia de 24 de enero de 2012

-Caso C.A.S. y C.S. contra Rumania, Sentencia de 20 Marzo de 2012

-Caso I.G. contra Moldavia, Sentencia de 15 de mayo de 2012

-Caso N.B contra Eslovaquia, Sentencia de 12 de junio de 2012

-Caso D.J contra Croacia, Sentencia de 24 de julio 2012

-Caso M. y otros contra Italia y Bulgaria, Sentencia de 1 de agosto de 2012

-Caso P. y S. contra Polonia. Sentencia de 30 de octubre de 2012

-Caso C.N. contra Reino Unido, Sentencia de 13 de noviembre de 2012

-Caso I.G y otros contra Eslovaquia, Sentencia de 13 de noviembre de 2012

-Caso R.K contra la República Checa, Decisión de 27 de noviembre de 2012 
-Caso Valiuliene contra Lituania, Sentencia de 26 de marzo de 2013 -Caso Maktouf y Damjanovic contra Bosnia, Sentencia de 18 de julio de 2013 -Caso M.A. contra Eslovenia, Sentencia de 23 de enero de 2014 -Caso W. contra Eslovenia, Sentencia de 23 de enero de 2014 -Caso O'Keeeffe contra Irlanda, Sentencia de 28 de enero de 2014 -Caso Rumor contra Italia, Sentencia de 27 de mayo de 2014 -Caso S.Z. contra Bulgaria, Sentencia de 3 de marzo de 2015 -Caso L.E. contra Grecia, Sentencia de 21 de enero de 2016 -Caso M.G.C. contra Rumania, Sentencia de 16 de marzo de 2016 -Caso A, B y C contra Letonia. Sentencia de 31 de marzo de 2016 -Caso G.J. contra España. Decisión de 12 de junio de 2016 -Caso Halime Kilıç contra Turquía, Sentencia de 28 de junio de 2016 -Caso J. y otros contra Austria, Sentencia de 17 de enero de 2017 -Caso Talpis contra Italia, Sentencia de 2 de marzo de 2017 -Caso B.V. contra Bélgica, Sentencia de 2 de mayo de 2017 -Caso Bălşan contra Rumania, Sentencia de 23 de mayo de 2017. -Caso Chowdury y otros contra Grecia, Sentencia de 30 de mayo de 2017 -Caso A.R. contra Suiza, Sentencia de 19 de diciembre de 2017 -Caso S.M. contra Croacia, Sentencia de 19 de julio de 2019 
